\section{Sea level and vertical motion of continents from dynamic earth models since the}

\section{Late Cretaceous}

\section{Sonja Spasojevic and Michael Gurnis}

\section{ABSTRACT}

Dynamic earth models are used to better understand the impact of mantle dynamics on the vertical motion of continents and regional and global sea level change since the Late Cretaceous. A hybrid approach combines inverse and forward models of mantle convection and accounts for the principal contributors to long-term sea level change: the evolving distribution of ocean floor age, dynamic topography in oceanic and continental regions, and the geoid. We infer the relative importance of dynamic versus other factors of sea level change, determine time-dependent patterns of dynamic subsidence and uplift of continents, and derive a sea level curve.

We find that both dynamic factors and the evolving distribution of sea floor age are important in controlling sea level. We track the movement of continents over large-scale dynamic topography by consistently mapping between mantle and plate frames of reference, and we find that this movement results in dynamic subsidence and uplift of continents. The amplitude of dynamic topography in continental regions is larger than global sea level in several regions and periods, so that it has controlled regional sea level in North and South America and Australia since the Late Cretaceous, northern Africa and Arabia since the late Eocene, and Southeast Asia in the Oligocene-Miocene. Eastern and southern Africa have experienced dynamic uplift over the last 20 to 30 m.y., whereas Siberia and Australia have experienced Cenozoic tilting. The dominant factor controlling global sea level is a changing oceanic lithosphere production that has resulted in a large amplitude sea level fall since the Late Cretaceous, with dynamic topography offsetting this fall.

Copyright (C)2012. The American Association of Petroleum Geologists. All rights reserved.

Manuscript received August 12, 2011; provisional acceptance November 21, 2011; revised manuscript received February 1, 2012; final acceptance March 26, 2012.

DOI:10.1306/03261211121

\section{AUTHORS}

SONJA SPASOJEVIC $\sim$ Seismological Laboratory, California Institute of Technology, 1200 East California Boulevard, MC 252-21, Pasadena, California; present address: BP America, Houston, Texas; Kisis1@bp.com

Sonja Spasojevic received a B.Sc. degree in geophysics from the University of Belgrade, Serbia, in 2001, and an M.Sc. degree in exploration geophysics from the University of Houston in 2003. After working for two years as a geophysicist for BP in the deep-water Gulf of Mexico, she joined the California Institute of Technology (Caltech) in 2005 to work on research related to the dynamics of long-term sea level change, vertical motion of continents, and evolution of sedimentary basins, with Michael Gurnis as advisor. After receiving her Ph.D. in geophysics in 2010, she continued working as a staff scientist at Caltech during 2011. She recently returned to BP America, working in the Brazil regional exploration team.

MiCHAEL GURNIS Seismological Laboratory, California Institute of Technology, Pasadena, California; gurnis@gps.caltech.edu

Michael Gurnis received a B.S. degree from the University of Arizona in 1982 and a Ph.D. from the Australian National University in 1987, both in geophysics. Following a postdoctoral research at the California Institute of Technology (Caltech), he was a faculty member at the University of Michigan. In 1994, he returned to Caltech where he is currently John E. and Hazel S. Smits Professor of Geophysics and director of the Seismological Laboratory. His effort is divided between linking geodynamics and the rock record (especially stratigraphy), the basic physics of geophysical phenomena, studies of the deep interior of the Earth, and the development of new computational methods, including the GPlates package for plate tectonic modeling.

\section{ACKNOWLEDGEMENTS}

All calculations were conducted at the California Institute of Technology (Caltech) Geosciences Supercomputer Facility, partially supported by National Science Foundation EAR-0521699. This work was supported through Statoil, the National Science Foundation (EAR-0810303), and the Caltech Tectonics Observatory (by the Gordon 
and Betty Moore Foundation). The original CitcomS software was obtained from the Computational Infrastructure for Geodynamics. This is contribution number 169 of the Division of Geological and Planetary Sciences and contribution number 10063 of the Tectonics Observatory, Caltech.

The AAPG Editor thanks the following reviewers for their work on this paper: Steven G. Henry and Peter Webb.

\section{DATASHARE 45}

High-resolution versions of Figures 2 and 4-8 with captions, and appendixes 1-3 may be seen on the AAPG Web site (www.aapg.org /datashare) as Datashare 45.

\section{INTRODUCTION}

Continental interiors experienced extensive marine inundation and sedimentation during the Cretaceous, associated with a global (eustatic) sea level high (Hallam, 1992). The marine inundation of North America is a clear example of the extensive flooding, where approximately $40 \%$ of the continent flooded, resulting in more than $1 \mathrm{~km}(>0.6 \mathrm{mi}$ ) of sediments being deposited over a horizontal scale of $1000 \mathrm{~km}$ (621 mi) (Bond, 1976; Liu and Nummedal, 2004). The eustatic change on time scales of millions of years may be controlled by changes in ocean basin volume caused by variations in oceanic spreading rates or ridge lengths (Hays and Pitman, 1973; Kominz, 1984). However, North American Cretaceous stratigraphic sequences (Sloss, 1963) suggest that observed continental-scale transgressional and regressional cycles cannot be explained by eustasy alone (Bond, 1976; Sleep, 1976) and that large-scale tectonic or dynamic mechanisms are required. Namely, analysis of the Cretaceous North America sediments suggests that the observed flooding would require a sea level rise of $310 \mathrm{~m}(1017 \mathrm{ft})$, resulting in accumulation of $700 \mathrm{~m}(2297 \mathrm{ft})$ of sediments (Bond, 1976), whereas the observed Cretaceous isopachs (Cook and Bally, 1975) are significantly thicker.

Continental flooding can be controlled by dynamic topography, a vertical deflection of the surface resulting from mantle flow (e.g., Richards and Hager, 1984). Although dynamic topography results in large-amplitude geoid anomalies, because these anomalies are small compared to topography (Hager, 1984), sea level variations should be mainly controlled by changes in dynamic topography (Gurnis, 1990). Early geodynamic studies explored the basic process of dynamic controls of sea level, developing simple two-dimensional (2-D) isoviscous models of convection that demonstrated that slabs create broad topographic depressions that can be filled with sediments (Mitrovica and Jarvis, 1985) and that continental flooding is influenced by movement of continents over large-scale patterns of dynamic topography (Gurnis, 1990). Early regional studies linked mantle dynamics and vertical motions with observations, and models of North America showed that general features of Phanerozoic strata can be explained by dynamic topography created by subduction and supercontinent aggregation and dispersal (Burgess et al., 1997). The extensive Cretaceous flooding resulting in the creation of significant hydrocarbon accumulations and the subsequent uplift of the Western Interior seaway (WIS) were interpreted first with simple 2-D dynamic models of Farallon slab subduction (Mitrovica et al., 1989) and, more recently, with three-dimensional (3-D) inverse models 
assimilating seismic tomography and plate motions (Liu et al., 2008; Spasojevic et al., 2009). Threedimensional models applied to Australia showed that anomalous Cretaceous vertical motions can be related to the movement of the continent over a slab associated with Gondwanaland-Pacific subduction while also explaining the anomalous geochemistry and geophysics of the present-day sea floor south of Australia (Gurnis et al., 1998; Gurnis et al., 2000b). Two episodes of long-wavelength tilting of the Russian platform during the Devonian to the Permian have been attributed to separate episodes of subduction (Mitrovica et al., 1996), whereas the excess subsidence of the Campbell plateau between 70 and $40 \mathrm{Ma}$ have been related to the drift of New Zealand away from a dynamic topography high associated with a Ross Sea mantle upwelling (Sutherland et al., 2009; Spasojevic et al., 2010a). Global models of mantle flow driven by paleogeographically constrained subduction match patterns of flooding in the Middle Ordovician, Late Permian, and Early Cretaceous (i.e., periods of flooding during eustatic highs) (Gurnis, 1993), as well as the Cenozoic uplift and subsidence of North America, Australia, and Indonesia (Lithgow-Bertelloni and Gurnis, 1997). In addition, it was demonstrated that dynamic topography should also modify the shape (depth) of the basins of the oceans globally, which will affect the time-dependent trends of sea level change (Gurnis, 1993; Conrad and Husson, 2009).

These studies demonstrate the importance of mantle dynamics in modulating global and regional sea levels, and in some cases, they have linked the models to stratigraphic constraints, but they have some limitations. Most dynamic topography models were in a mantle frame, with the exception of the regional models of Australia (Gurnis et al., 1998; Gurnis et al., 2000b; DiCaprio et al., 2009) and North America (Liu et al., 2008; Spasojevic et al., 2009), whereas geologic observations are made in the plate frame of reference. Previous global models of sea level change have not accounted for long-term factors of sea level change self-consistently. Here, we present spherical dynamic earth models (DEMs) since the Late Cretaceous that overcome these limitations by assimilating plate tectonic reconstructions into variable viscosity models of mantle convection. We combine inverse and forward methods for solving for mantle convection, allowing estimates of initial conditions with improved formulations for density, viscosity, and convergent plate margins. We also use globally distributed stratigraphic data to constrain the control of the mantle on uplift and subsidence, and regional and global sea level change. Global DEMs are computed in the mantle frame, but the integrated plate reconstruction-mantle convection system enables a linkage with geologic observations in plate frames of reference. We first compute the shape of the ocean and eustasy that accounts for changing ocean floor age (OFA) (Müller et al., 1997; Müller et al., 2008b), time-dependent dynamic topography, and the geoid. Second, we compute marine inundation and paleoshorelines within continental interiors and compare them with geologic observations. Such DEMs account for the most important factors controlling long-term sea level change self-consistently, and from them, we infer the relative importance of different factors for the control of vertical motions and tilting of continents and sea level change since the Late Cretaceous.

Dynamic earth models provide an improved understanding of the effects of mantle dynamics on subsidence, uplift, and tilting of continents that have important implications for petroleum systems. Mantle dynamics affect basin subsidence and sedimentation and, in turn, the deposition of source rock, reservoirs, and seals. Dynamic uplift can affect petroleum systems through the cessation of the active hydrocarbon maturation or expulsion of hydrocarbons, variability in sediment supply, affecting evolution of drainage patterns, and tilting of sedimentary sequences and traps. One of the goals of DEMs is to understand which sedimentary basins have been affected by mantle dynamics, with the hope that these findings will be incorporated into hydrocarbon exploration workflows.

\section{METHOD}

Dynamic earth models link plate reconstructions and seismic images with forward and inverse mantle convection models, in which the resulting model 
Figure 1. GPlates reconstructions at 90 , 60 , and $30 \mathrm{Ma}$. The colors represent the reconstructed age of the sea floor (Müller et al., 2008a); the arrows show plate velocities in the moving hotspot frame of reference. The black lines with filled black triangles indicate the position of subduction zones, whereas the plain black lines indicate ridges and transform plate boundaries.
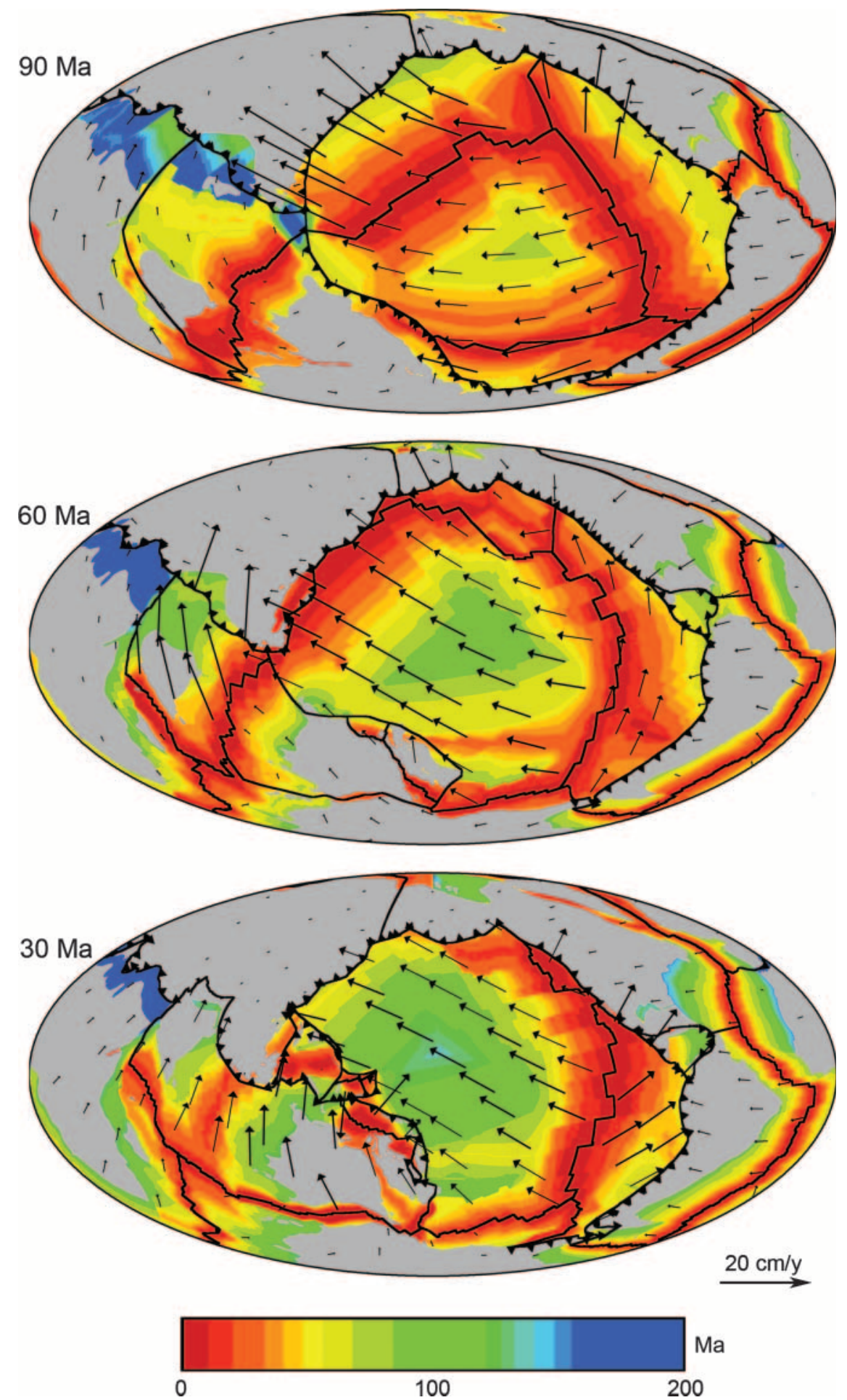

predictions are compared with stratigraphic observations. Dynamic earth models are developed for the periods spanning the Late Cretaceous to the present, with a goal of improving our understanding of the history of the vertical motion of the surface of earth and global and regional sea levels.

\section{Plate Reconstructions}

We use plate reconstructions in which plate geometry is represented as continuously evolving closed plate polygons using the GPlates package (Boyden et al., 2011) (Figure 1). Each plate is defined as a rigid plate with its own Euler pole and a set of 
evolving margins, each having a different Euler pole (Gurnis et al., 2012) defined in a moving hotspot reference frame (Müller et al., 2008a). Continuously evolving plate margins are necessary so that slabs remain coherent as they continuously subduct. We dynamically close plates by continuously finding the intersection of all margins with no gaps or overlaps between adjacent plates (Gurnis et al., 2012). The continuously closed plate polygons are selfconsistent with paleoage grids that give the age of oceanic lithosphere (Müller et al., 2008a). The time interval between reconstructions can be as small as needed, but here, we use 1 m.y.

Different aspects of the plate reconstructions are assimilated into the DEMs. First, plate velocities, defined at 1-m.y. steps and linearly interpolated at intermediate times, are used as a surface kinematic boundary condition on the convection models. Second, the position and character of plate boundaries are used to define buoyancy associated with subduction in hybrid models. Third, the paleoage grids are used with the hybrid models, as well as for global time-dependent sea level calculations. Finally, the plate reconstructions are used for mapping outputs from the mantle to plate frames of reference using closed plate polygons and rotation poles, enabling the comparison of model predictions with stratigraphic constraints.

\section{Mantle Convection Models}

Models of mantle convection are formulated using the finite-element code CitcomS version 3.2 (Zhong et al., 2000; Tan et al., 2006), which solves the equations of mass, momentum, and energy conservation for an incompressible Newtonian fluid while making the Boussinesq approximation. Previous mantle convection models investigating dynamic effects on sea level are defined either as forward or inverse models. The main limitation of forward models, run from the geologic past to the present, is the unknown past structure of the mantle. Inverse models, however, are run from the present to the past, with the present-day mantle structure constrained by seismic tomography. However, inverse models are limited by (1) not being able to reverse thermal diffusion to predict past structures, which is reasonable for the mantle interior, away from boundary layers, on time scales studied here (Conrad and Gurnis, 2003; Liu and Gurnis, 2008); (2) the long-wavelength and lowresolution mantle structure; and (3) the inability to realistically treat subduction zones in viscous models (Liu et al., 2008).

Here, we formulate hybrid geodynamic models that combine inverse (Conrad and Gurnis, 2003; Liu and Gurnis, 2008) with forward models, to overcome their individual limitations. First, we simply integrate backward (e.g., simple backward integration [SBI] method of Liu and Gurnis, 2008) from the present to the Late Cretaceous with kinematic surface velocity by reversing the direction of plate motions (Figure 1). The initial global SBI temperature field at $0 \mathrm{Ma}$ is defined from seismic tomographic inversions of surface and body waves using models SB4L18 (Masters et al., 2000) or S20RTS (Ritsema et al., 2004), with tomographyto-density scaling constrained by fitting the observed geoid (Spasojevic et al., 2010b). Second, we create a hybrid buoyancy field in the past by merging the SBI with synthetic subducted slabs. For each time step in the past, we define lower mantle buoyancy from the SBI, whereas in the upper mantle, we merge high-resolution synthetic slabs with positive buoyant anomalies from the SBI. The geometry and thermal structure of subducted slabs in the upper mantle are defined from the reconstructed subduction zones from GPlates (Figure 1), age of the subducted lithosphere (Müller et al., 2008a), and relations among subduction zone parameters (C. Tape et al., 2011, unpublished work). Simple backward integration buoyancy is stripped from the upper $250 \mathrm{~km}$ (155 mi) of the mantle, as it is likely close to neutral buoyancy (Jordan, 1988; Goes and van der Lee, 2002).

Finally, the Stokes equation is solved in a forward model with this hybrid buoyancy, imposing a no-slip boundary condition at the top surface to obtain the dynamic topography and geoid. Dynamic topography on the top surface is determined from the total normal stress in the radial direction while accounting for self-gravitation (Zhong et al., 2008). Figure 2 shows the predicted dynamic topography, geoid, and buoyancy for a hybrid model. 
A
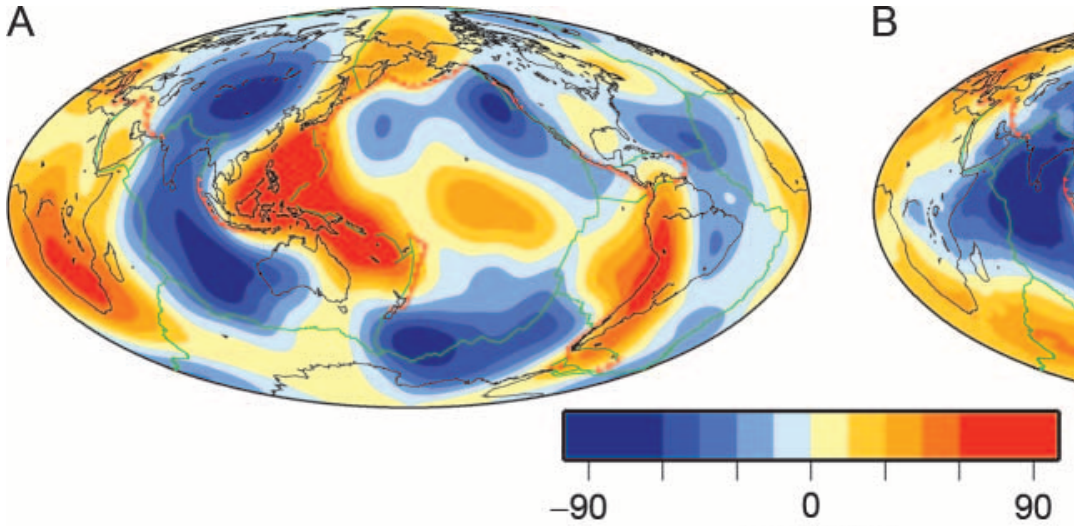

Geoid (m)

C
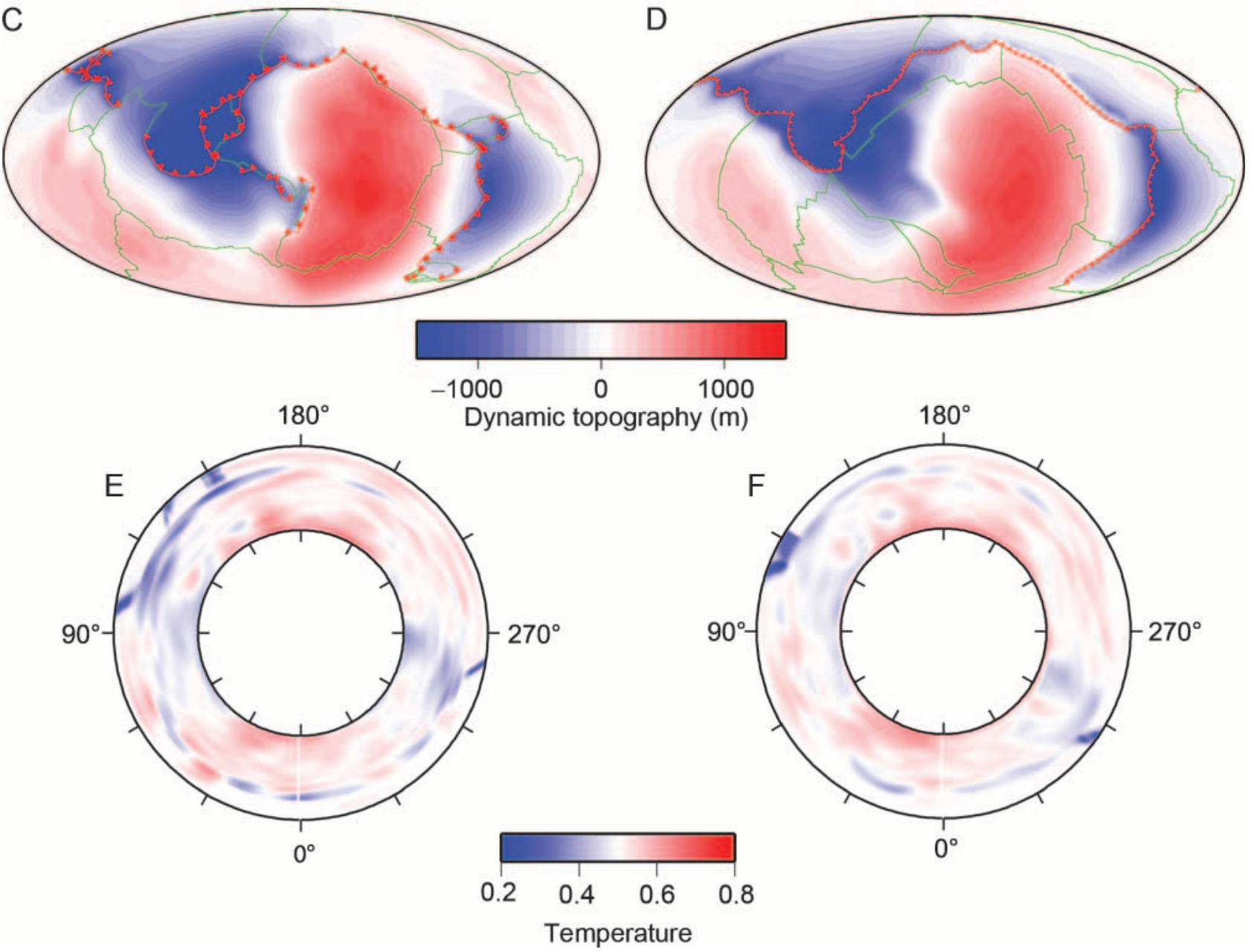

$(\mathrm{m})$

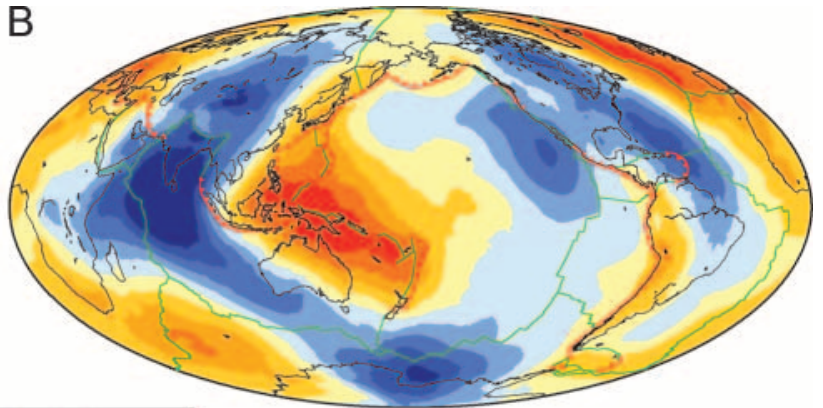

Figure 2. Dynamic topography and geoid prediction for model M3. (A) Predicted geoid at 0 Ma. (B) Observed geoid. (C-D) Predicted dynamic topography at $0 \mathrm{Ma}(\mathrm{C})$ and $80 \mathrm{Ma}(\mathrm{D})$. (E-F) Global equatorial spherical cross section through nondimensional temperature field at $0 \mathrm{Ma}(\mathrm{E})$ and $80 \mathrm{Ma}(\mathrm{F})$. See a high-resolution version on Datashare 45, www.aapg.org/datashare.

A four-layer mantle-viscosity structure, consisting of a high-viscosity lithosphere, upper mantle, transition zone, and lower mantle, is modified by a temperature-dependent viscosity, which introduces lateral viscosity variations, shown to be an important influence on dynamic topography and the geoid in subduction zones (Billen and Gurnis, 2001; Billen et al., 2003) and for present-day plate motions 


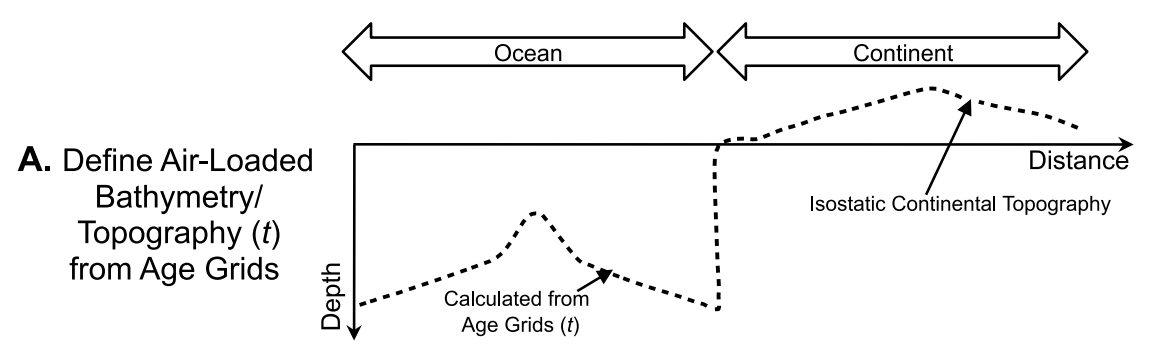

B. Define Air-Loaded Topography Modified by Dynamic Topography $(t)$

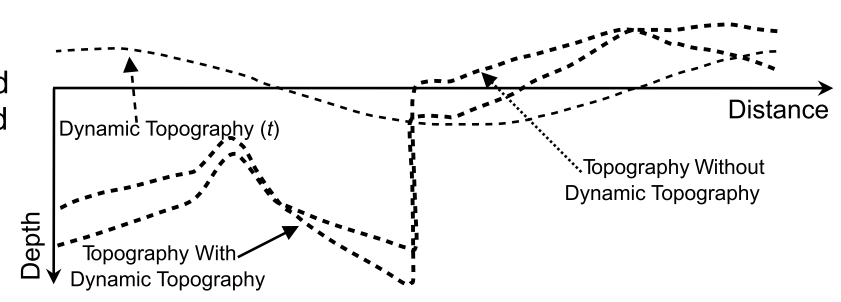

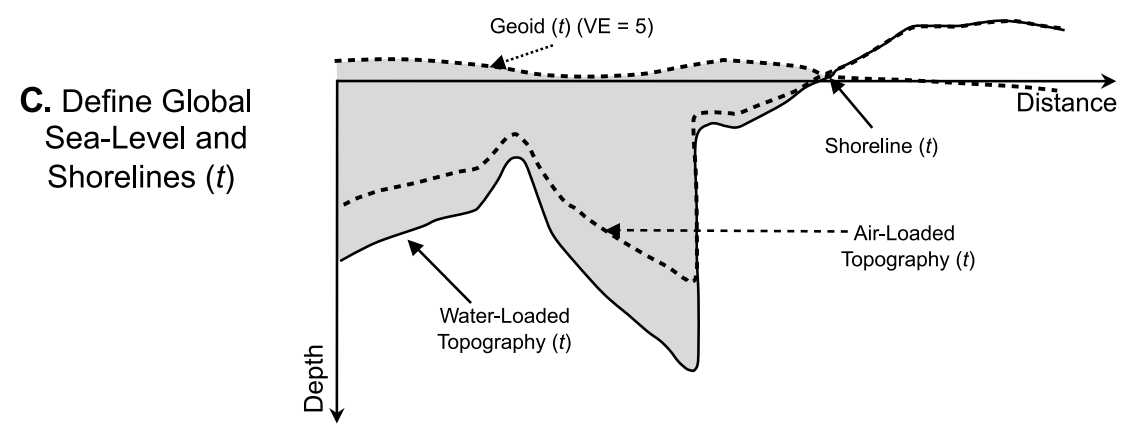

Figure 3. Two-dimensional schematic of the algorithm used for global sea level calculations in dynamic earth models, with $t$ denoting time. $\mathrm{VE}=$ vertical exaggeration.
(Stadler et al., 2010). Details of the viscosity, resolution, and other model parameters are given in Appendix 1 (see Datashare 45 at www.aapg.org /datashare).

\section{Paleogeographic Constraints and Relative Sea Level Changes}

The primary geologic constraints are a set of published global and regional inferred paleoshorelines from the Late Cretaceous to the present. We use two sets of global Cretaceous and Cenozoic shorelines, one from Smith et al. (1994), determined at every 10-m.y. intervals from 90 to $10 \mathrm{Ma}$, and a second from Blakey (2008), defined for the Late Cretaceous (90 Ma), Cretaceous-Tertiary boundary (65 Ma), Eocene (50 Ma), Oligocene (35 Ma), and Miocene (20 Ma). We also use a regional set of reconstructions for (1) northern and central Africa and Arabia (Guiraud et al., 2005) in latest Albianearly Senonian (98.9-85 Ma), late SantonianMaastrichtian (84-65 Ma), Paleocene (65-54.8 Ma), early middle Eocene (54.8-37 Ma), Oligocene (33.723.8 Ma), and Miocene (23.8-5.3 Ma); (2) Southeast Asia (Hall and Morley, 2004) in late Oligocene (28.4-23 Ma), early Miocene (23-16 Ma), and middle Miocene (16-11.6 Ma); and (3) Australia at 77, $68,60,44,33,20,8$, and $4 \mathrm{Ma}$ (Langford et al., 1995), with numerical ages indicating the middle of the respective reconstruction periods. Division into marine and subaerial units simplifies the paleoshoreline maps.

We infer relative sea level change by differencing these maps between a more recent $\left(t_{1}\right)$ and an earlier age $\left(t_{2} ; t_{2}>t_{1}\right)$. Marine regression occurs when a submerged area at $t_{2}$ is exposed above the sea level at $t_{1}$, implying a eustatic fall, a sedimentation rate that outpaces accommodation space 
creation regionally, or a relative uplift regionally (Hallam, 1992). Marine transgression occurs when a subaerially exposed area at $t_{2}$ is flooded at a subsequent period $t_{1}$, which can be the result of a eustatic rise, a sea level rise outpacing sedimentation regionally, or regional subsidence. When an area of interest is subaerially exposed (or flooded) at both times, may be also experiencing vertical motions and sedimentation, but with amplitudes and wavelengths insufficient to result in changes of flooding.

We compare maps of relative sea level change to maps of differential dynamic topography, created by subtracting dynamic topography at time interval $t_{1}$ from dynamic topography at $t_{2}\left(t_{1}<t_{2}\right)$. We hypothesize that a good agreement between maps of relative sea level change and maps of differential dynamic topography might imply that dynamic topography is one of the factors contributing to the observed regional shoreline migration. If such agreement does not exist, then shoreline migration is likely controlled by factors other than mantle convection-induced subsidence and uplift. This reasoning will be limited if the hybrid model fails to predict the correct trends in dynamic topography because of incorrect estimates of the mantle buoyancy field. We attempt to overcome this limitation by finding alternative dynamic models that provide a better agreement between differential dynamic topography and inferred relative sea level change.

\section{Global Sea Level Calculations}

To calculate global sea level, we first determine global topography at each time step $t$ (Figure 3A and $\mathrm{B}$ ), which is subsequently inundated for paleoshoreline predictions (Figure 3C). The oceancontinent function is defined from oceanic age grids (Müller et al., 2008a), such that areas with OFAs are defined as oceanic, and the remaining are assumed continental. For oceanic regions, bathymetry is nominally determined from age-depth relationships (Figure 3A) using a half-space thermal cooling model (Parsons and Sclater, 1977) without flattening:

$$
d=2500 \mathrm{~m}+350 \mathrm{~m} \sqrt{t}
$$

where $d$ is ocean floor depth in meters and $t$ is seafloor age in million years. We assume a half space without flattening because age-depth relationships that include flattening (Parsons and Sclater, 1977; Stein and Stein, 1992) likely have a component of dynamic topography. The air-loaded topography of ocean floor is

$$
d_{\mathrm{al}}=\frac{\rho_{\mathrm{m}}-\rho_{\mathrm{w}}}{\rho_{\mathrm{m}}-\rho_{\mathrm{a}}} \times d=0.689 \times d
$$

where $d_{\mathrm{al}}$ is the air-loaded depth of ocean floor, and $\rho_{\mathrm{m}}, \rho_{\mathrm{w}}$, and $\rho_{\mathrm{a}}$ are the densities of mantle, water, and air, respectively (Appendix 1).

For continental regions, we first define air-loaded isostatic topography (Figure 3A). At present, the topography is assumed to be the sum of an isostatic and a dynamic component. We determine the isostatic component at time $t$ by subtracting the predicted dynamic topography at $0 \mathrm{Ma}$ from the observed topography (Figure 3A) and merging the rotated field for each plate from $0 \mathrm{Ma}$ to time $t$. This assumes that isostatic topography remains unchanged from $0 \mathrm{Ma}$ to time $t$, a significant limitation in places because it ignores orogenesis and complicates global sea level predictions. The final airloaded topography at time step $t$ is obtained by summing air-loaded dynamic topography (Figure 3B) and isostatic topography.

The air-loaded global topography is then inundated (Figure 3C). Starting with the lowest parts of the air-loaded topography, we fill depressed areas with the present-day volume of ocean water so that the water surface conforms to the evolving geoid, which is well predicted at present (Figure 2) (Spasojevic et al., 2010b). In areas covered with water, isostatic adjustment for water loading is applied, and the final topography is a combination of water-loaded areas and air-loaded continents (Figure 3C). Paleoshorelines are the intersection of the final topography, with the ocean surface (Figure 3C) at each time step. We compare shoreline predictions that only account for the changing OFA with those that account for dynamic topography, geoid, and OFA (DYN-OFA). We infer the relative importance of dynamic factors versus ocean floor age on sea level change based on the comparison 
Table 1. Hybrid Model Summary

\begin{tabular}{lcccccc}
\hline Model Name & M1 & M2 & M3 & M4 & M5 & M6 \\
\hline Tomography model in SBI* & S20RTS & S20RTS & S20RTS & SB4L18 & SB4L18 & SB4L18 \\
Average transition zone to lower mantle viscosity ratio & $1: 20$ & $1: 60$ & $1: 100$ & $1: 20$ & $1: 60$ & $1: 100$ \\
\hline
\end{tabular}

*SBI = simple backward integration.

of these two predictions at $80 \mathrm{Ma}$ (Late Cretaceous), $60 \mathrm{Ma}$ (early Cenozoic), and $30 \mathrm{Ma}$ (mid-Cenozoic). Results for India are excluded because they are biased by the time-invariant isostatic assumption (because of the Himalayan orogen).

We also attempt to quantify global sea level change (1) because of variations in ocean age using the half-space model without flattening (equation 1; OFA-HS), half-space model with flattening (Appendix 1; OFA-HSF), and global depth and heat flow (GDH)-1 model (Stein and Stein, 1992) (Appendix 1; OFA-GDH) by calculating mean ocean bathymetry using relationships 4 to 7 in Appendix 1; and (2) by calculating variations in sea level for DYN-OFA with the half-space cooling model while tracking contributions caused by dynamic topography in oceanic regions (e.g., regions with defined OFAs in age grids), dynamic topography in flooded continental regions (e.g., regions that are predicted to be inundated but have no values of OFAs in age grids), and geoid. The DYN-OFA sea level estimates are corrected for sedimentation and ocean plateau emplacement using previously published time-dependent estimates (Müller et al., 2008a).

\section{RESULTS}

\section{Global Dynamic Topography}

We compute six hybrid models (Table 1) for three different radial viscosity profiles and two seismic tomography models. The reference viscosity is $10^{21} \mathrm{Pas}$ (Appendix 1), and an upper mantle average background viscosity of $10^{20} \mathrm{~Pa} \mathrm{~s}$ is observed for all models. Dynamic topography decreases with increasing lower mantle viscosity (Appendix 2, see AAPG Datashare 45 at www.aapg.org/datashare). The largest dynamic topography lows are located in the regions of subduction, so that, at $0 \mathrm{Ma}$, large dynamic topography lows develop in the western Pacific, Southeast Asia, South America, and the Mediterranean. During the Late Cretaceous, dynamic topography lows are in western North America, associated with subduction of the Farallon slab, and the region of Alpine Tethys subduction. Dynamic topography highs are associated with oceanic regions (Pacific Ocean, Northern Atlantic, and Indian Ocean) and Africa between the Late Cretaceous and the present (Appendix 2).

\section{Regional Sea Level and Vertical Motions}

\section{North America}

North America experienced a widespread marine inundation during the Late Cretaceous, resulting in the development of the WIS (Sloss, 1988), followed by an extensive uplift during the Laramide orogeny (English and Johnston, 2004). Maps of Late Cretaceous relative sea level (Figure 4A) show the WIS being continuously flooded, its eastern edge experiencing marine transgression, and the rest of North America remaining subareal and presumably high (Smith et al., 1994; Blakey, 2008). Dynamic earth models predict an increasing dynamic topography low in the WIS (Figure 4A), with the western edge being aligned with the Sevier belt. Model M4 predicts well the eastern edge of the WIS, whereas model Ml predicts a wider differential dynamic topography low covering both the WIS and eastern North America (Figure 4A). Cenozoic relative sea level maps indicate that North America either experienced an uplift or remained high (Figure 5A). Dynamic earth models predict accumulated dynamic uplift of western North America (Figure 5A) over the Cenozoic and dynamic subsidence of the eastern part of the continent, with the East Coast subsiding between 100 and $400 \mathrm{~m}$ (328 and $1312 \mathrm{ft}$ ). 


\section{A}

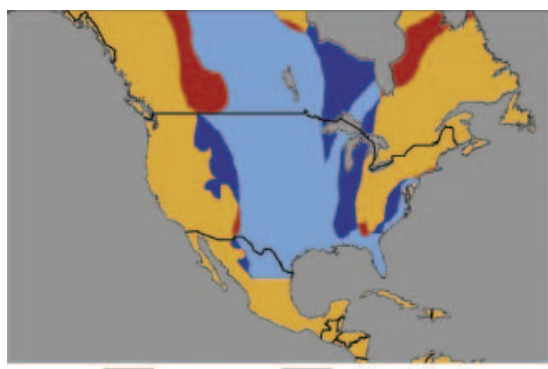

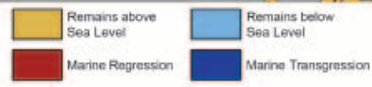

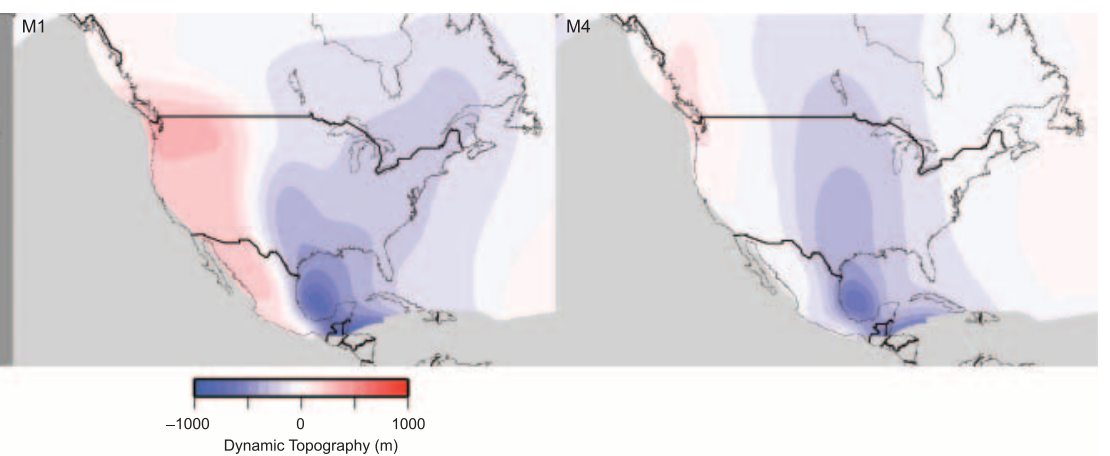

$\mathrm{B}$
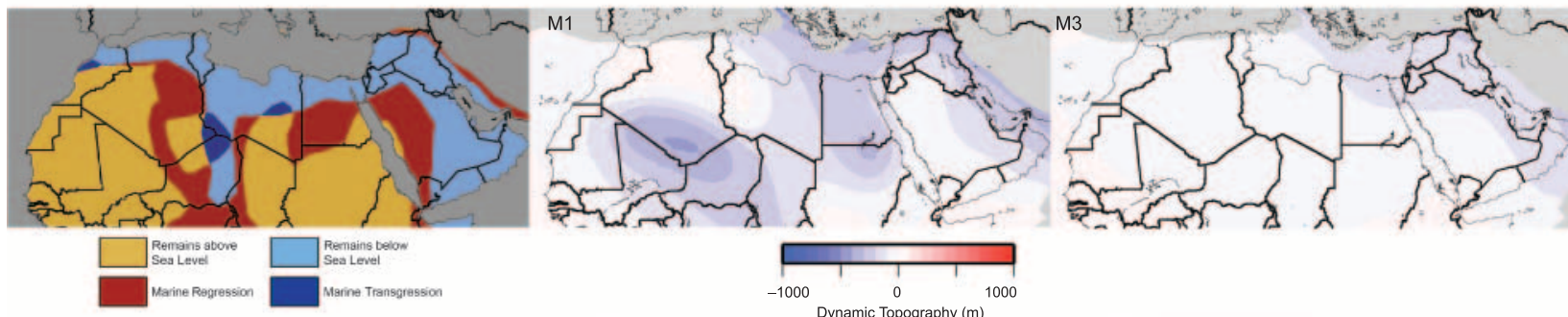

C
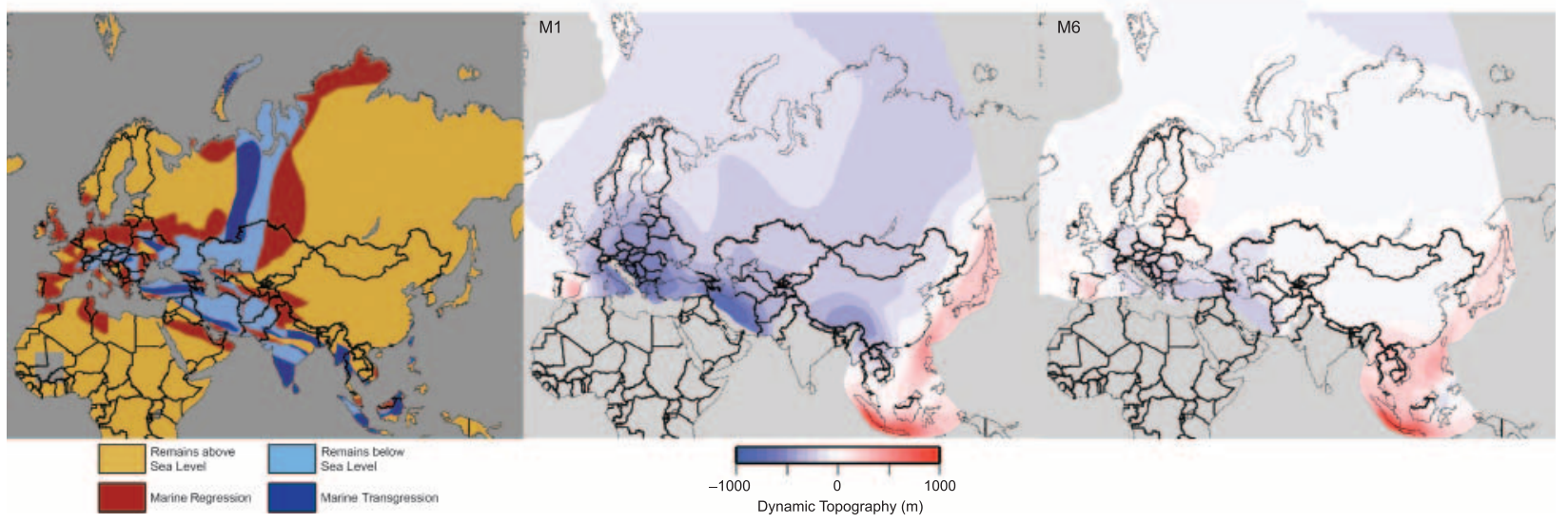

D

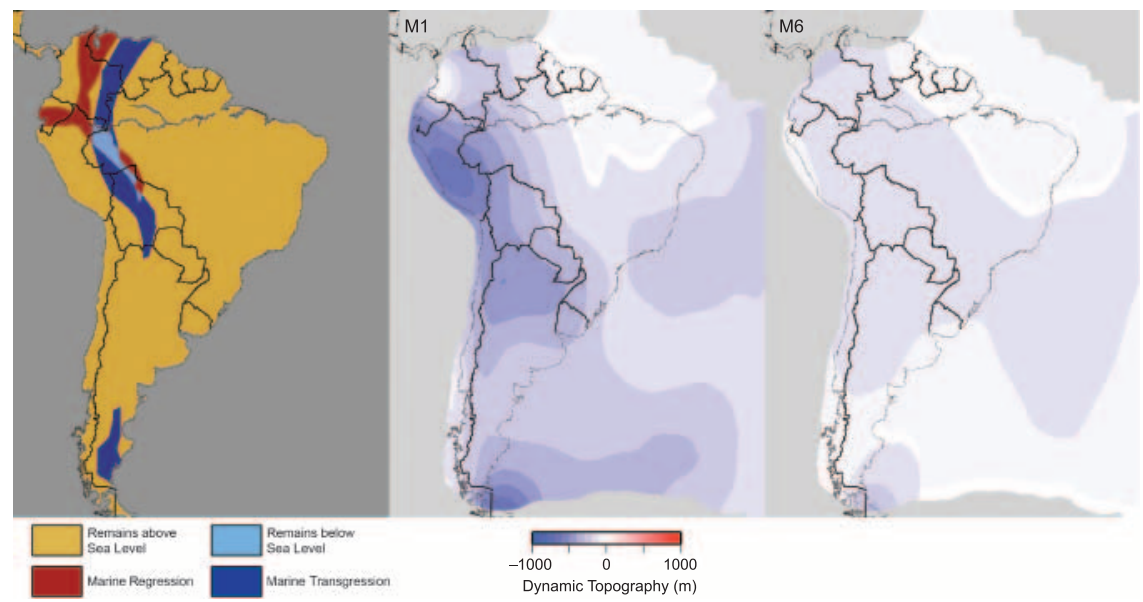

Figure 4. Inferred relative sea level change in the Late Cretaceous for North America (A), northern Africa and Arabia (B), Eurasia (C), South America (D), and Australia (E). The first image in panels A to $E$ represents relative sea level inferred from paleogeography using reconstructions at 70 and $90 \mathrm{Ma}$ (Smith et al., 1994) (A); late Santonian-Maastrichtian and latest Albian-early Senonian (Guiraud et al., 2005) (B); 65 and $90 \mathrm{Ma}$ (Blakey, 2010) (C-D); and 60 and $77 \mathrm{Ma}$ (Langford et al., 1995) (E). Relative vertical motions inferred from dynamic models are shown, with " $\mathrm{M}$ " corresponding to the specific hybrid model (Table 1). See a high-resolution version on Datashare 45, www.aapg.org/datashare. 

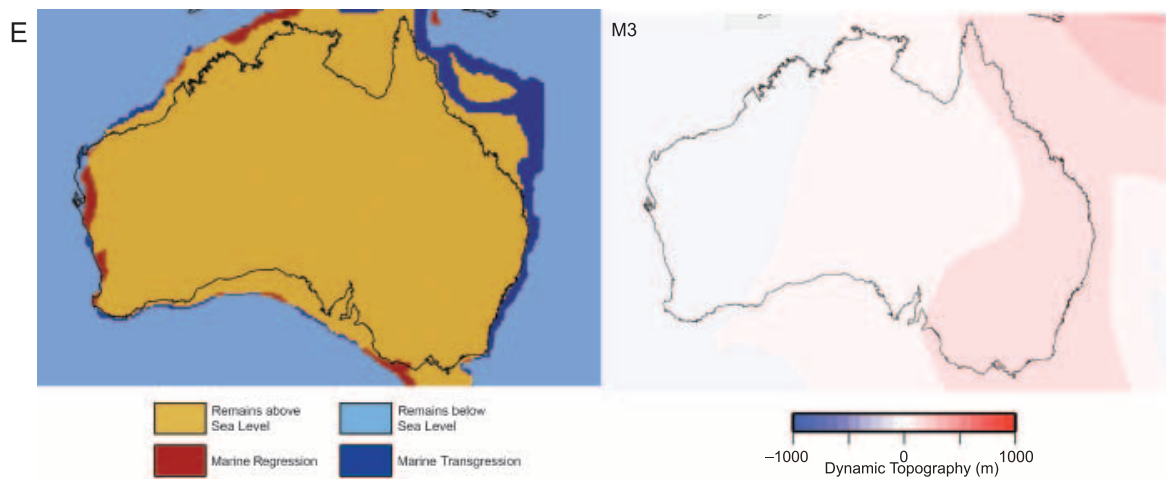

Figure 4. Continued.
The predicted pattern of vertical motions (Table 2) is related to the subduction of the Farallon slab. Remnants of the Farallon slab are presently imaged as a north-south-trending, highseismic velocity, mid-mantle anomaly under the East Coast of North America (Masters et al., 2000; Grand, 2002; Ritsema et al., 2004). As the mantle flow and plate motions are reversed in the SBI from the present to the Late Cretaceous, the Farallon slab rises upward, and North America moves eastward in the mantle frame of reference, so that it is located in the upper mantle under the WIS during the Late Cretaceous. High-density Farallon slab creates a dynamic topography low with an amplitude of approximately $1 \mathrm{~km}(\sim 0.6 \mathrm{mi})$ (Appendix 2), resulting in $500 \mathrm{~m}(1640 \mathrm{ft})$ of Late Cretaceous dynamic subsidence (Figure 4A). We could not match the observations of differential vertical motions and flooding without the introduction of a shallowdipping slab, with a dip of approximately $10^{\circ}$, similar to previous studies that propose a shallow to flat-lying Farallon slab during the Late Cretaceous (Mitrovica et al., 1989; Liu et al., 2008; Spasojevic et al., 2009), which could be potentially related to the subduction of the Shatsky oceanic plateau conjugate (Liu et al., 2010). As North America moves westward in the mantle reference frame from the Late Cretaceous to the present, and the Farallon slab sinks into the lower mantle, the dynamic topography low migrates eastward in the plate frame, resulting in an overall Cenozoic subsidence of eastern North America and a dynamic uplift in the west (Figure 5A). The Cenozoic subsidence does not create land subsidence because it is contemporaneous with an overall sea level fall. The proposed dynamic subsidence may help explain discrepancies between most global sea level curves and those derived exclusively on the New Jersey coastal margin (Spasojevic et al., 2008). The timing of the Laramide orogeny is currently debated but it probably initiated in the Late Cretaceous, and the proposed timing of its termination ranges from 35 to

Table 2. Inferred Dynamic Subsidence (-) and Uplift (+) from Dynamic Earth Models

\begin{tabular}{lccc}
\hline Continent & Late Cretaceous & Paleocene-Eocene & Oligocene-Miocene \\
\hline North America (Western Interior seaway) & - & + & + \\
North America (east) & - & - & - \\
Northern Africa & & - & - \\
Southern and eastern Africa & + & - & + \\
Southeast Asia & - & Siberian tilt & - \\
Eurasia (north-central) & - & - & Siberian tilt \\
Alpine Tethys & - & - & - \\
South America (Western Interior) & - & - & - \\
South America (Amazon) & & - & - \\
South America (Patagonia) & $+(?)$ & & + \\
Australia & & &
\end{tabular}



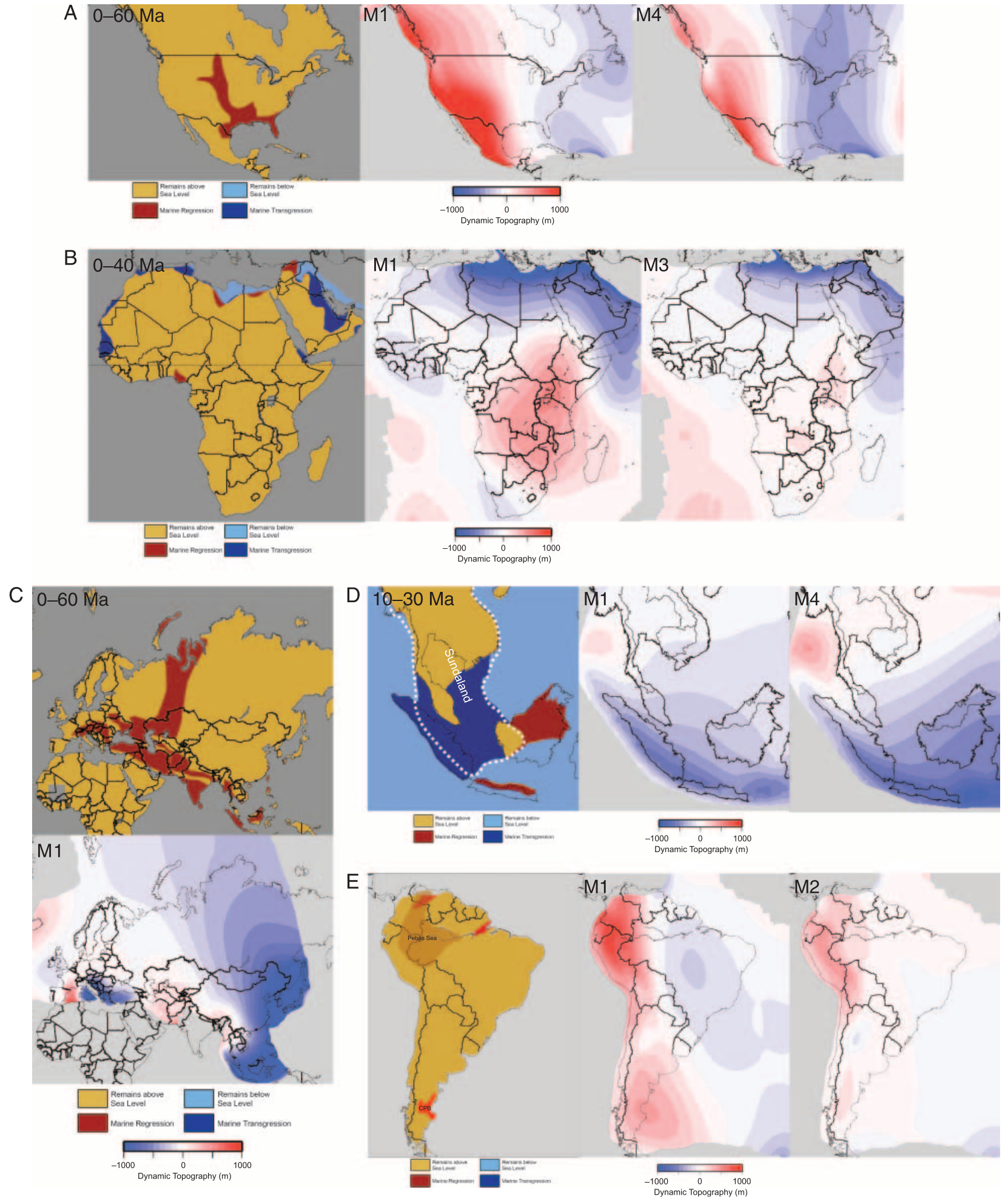

Figure 5. Inferred relative sea level change in the Cenozoic: 0 to $60 \mathrm{Ma}$ in North America (A); 0 to $40 \mathrm{Ma}$ in northern Africa and Arabia (B); 0 to $60 \mathrm{Ma}$ in Eurasia (C); 10 to $30 \mathrm{Ma}$ in Southeast Asia (D); 0 to $20 \mathrm{Ma}$ in South America (E); and 0 to $60 \mathrm{Ma}$ in Australia (F). The first image in panels A to E represents relative sea level inferred from paleogeography using reconstructions at $60 \mathrm{Ma}$ (Smith et al., 1994) (A); Miocene and early-middle Oligocene in northern Africa (Guiraud et al., 2005) and 35 Ma in southern and central Africa (Blakey, 2010) (B); $65 \mathrm{Ma}$ (Blakey, 2010) (C); middle Miocene and late Oligocene (Hall and Morley, 2004) (D); $20 \mathrm{Ma}$ (Blakey, 2010) (E), and $60 \mathrm{Ma}$ (Langford et al., 1995) (F). Relative vertical motions inferred from dynamic models are shown, with " $M$ " corresponding to the specific hybrid model (Table 1). CPB = central Patagonian Basin. The legend is the same as for Figure 4. See a high-resolution version on Datashare 45, www.aapg.org/datashare. 

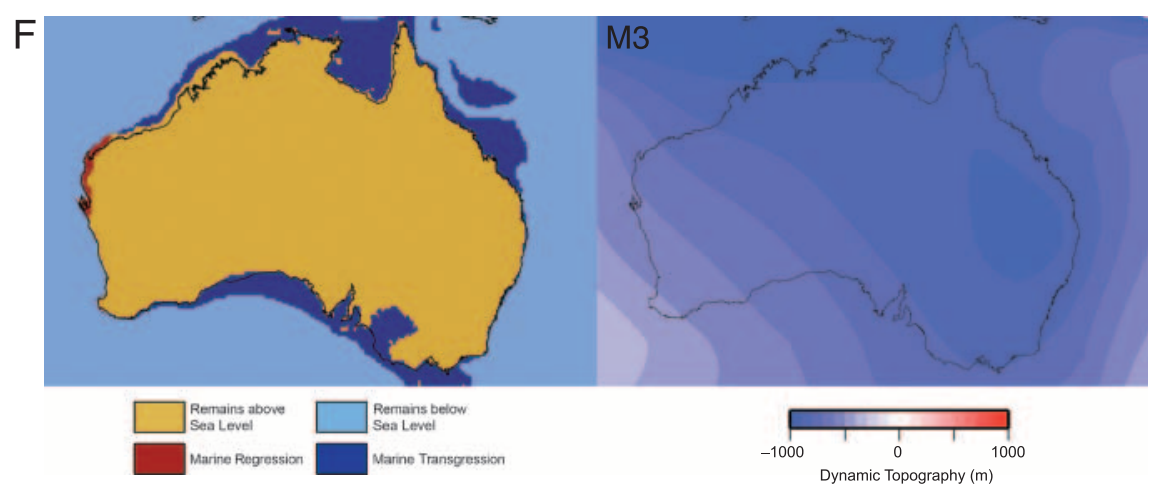

Figure 5. Continued.

$50 \mathrm{Ma}$ (Bird, 1998) to the Holocene (Bird, 1998; Liu et al., 2010). We find that a continuous dynamic contribution to the western North America (NAM) uplift has existed since the end of the Late Cretaceous (Figure 5A), resulting from the movement of the Farallon slab away from this region, similar to the findings of adjoint geodynamic models (Spasojevic et al., 2009).

Predicted Late Cretaceous flooding patterns in North America are closer to the observations in DYN-OFA calculations, compared to estimates made solely from the changing age of sea floor (Figure 6; Table 3), further suggesting that the dynamic effects of the Farallon subduction are important in controlling NAM flooding and associated deposition of thick hydrocarbon-bearing sedimentary sequences. The predicted Late Cretaceous flooding is shifted toward the east compared to that inferred (Figure 6), related to the assumed isostatic topography containing Laramide orogen. Early Cenozoic flooding is slightly better predicted when dynamic effects are considered (Figure 7), whereas the Oligocene-Miocene flooding is equally well predicted in the OFA and DYN-OFA models (Figure 8). This suggests that the dynamic effects probably are a secondary factor in controlling Cenozoic flooding.

\section{Africa and Arabia}

Paleogeographic maps (Guiraud et al., 2005) show continuous flooding of northernmost Africa and eastern Arabia and a shifting pattern of marine transgression and regression in the northern African interior during the Late Cretaceous (Figure 4B). Dynamic earth models predict a long-wavelength dynamic subsidence of northern and western Africa and Arabia (Figure 4B; Table 2). For model Ml, dynamic subsidence is concentrated in three regions: central western Africa, northeastern Africa, and Arabia, broadly equivalent to inferred marine transgression (Figure 4B). The dynamic subsidence results from the combined effect of the overall northward mantle flow of large, positively buoyant lower mantle structures and isolated, negatively buoyant structures in the uppermost lower mantle below the central part of western Africa. The complex inundation patterns in the interior of northern and western Africa are not predicted by the dynamic models (Figures 6-8). This is expected because it was proposed that African intracontinental seas developed in response to the northwest-southeasttrending to north-south-trending intracontinental rifting (Guiraud et al., 2005) ignored in the current DEMs. The relationship between geologically inferred and predicted vertical motions indicates that dynamic topography is a secondary factor controlling regional sea level and that other effects, such as eustatic changes caused by the changing age of sea floor and/or rift tectonics (Guiraud et al., 2005), are a significantly more important factor.

From the late Eocene to late Miocene, a pronounced transgression in eastern Arabia is observed, whereas the eastern parts of the northern African margin remained continuously flooded (Figure 5B) (Guiraud et al., 2005), coincident with an overall fall in global sea level, empirically suggesting sea level controls beyond eustasy. Dynamic earth models show an overall dynamic subsidence in the last 40 m.y. (Figure 4B; Table 2) in the regions of eastern northern Africa and Arabia. The proposed subsidence and Cenozoic tilt of the Arabian platform 

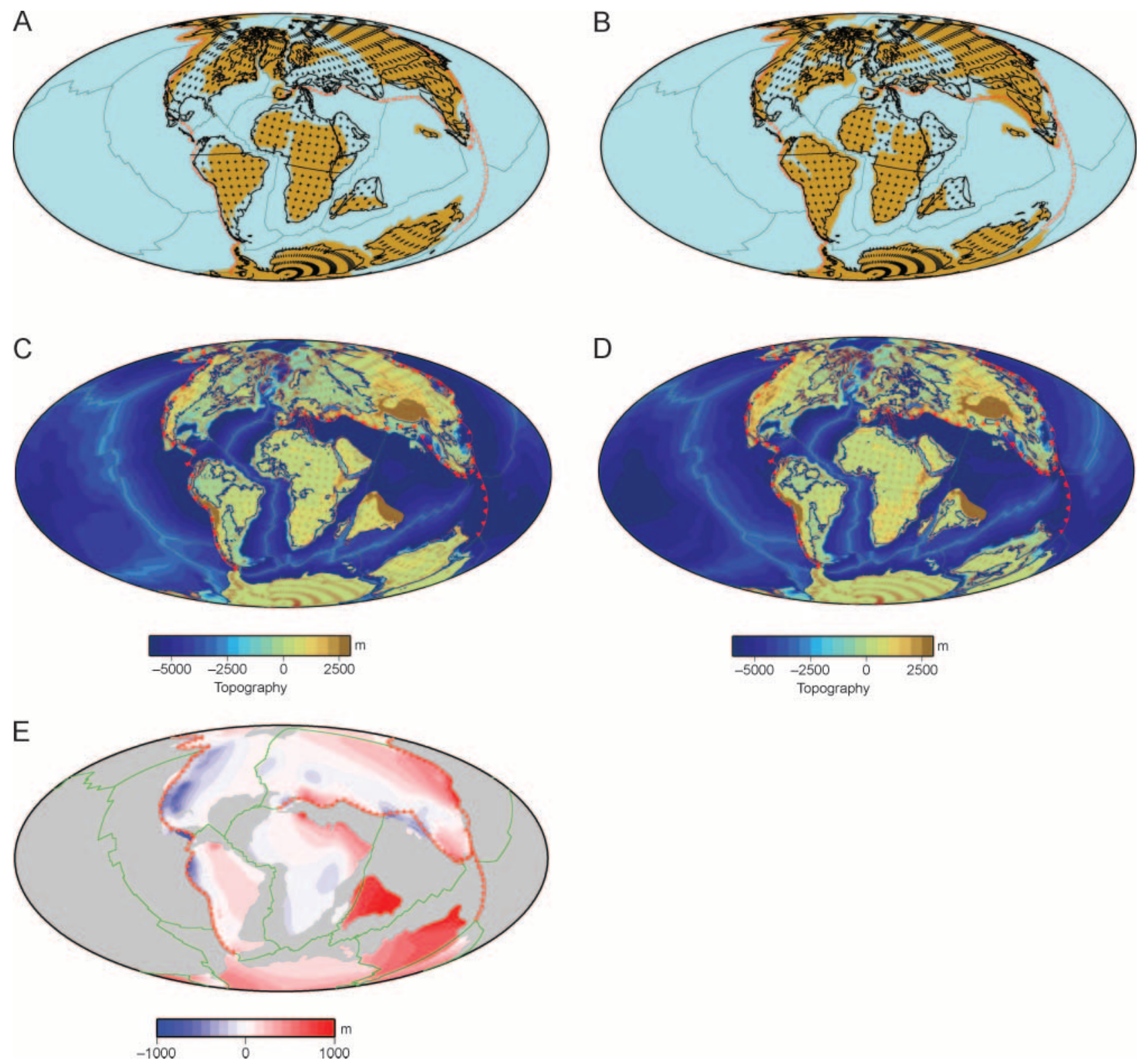

Figure 6. Late Cretaceous global sea level predictions. Paleogeographic reconstructions at 80 Ma (Smith et al., 1994) (A) and 90 Ma (B) (Blakey, 2010), showing reconstructed marine regions in light blue and land regions in brown. (C) DYN-OFA flooding predictions (80 Ma) accounting for the changing age of the ocean floor, dynamic topography, and geoid, using model M3 (Table 2). (D) OFA flooding predictions $(80 \mathrm{Ma})$ accounting only for the changing age of the ocean floor using the half-space model without flattening (Parsons and Sclater, 1977). (E) Difference between dynamic topography in the past ( $80 \mathrm{Ma}$ ) and present-day predicted dynamic topography for model M3. The dark blue lines on panels $C$ and D show a predicted shoreline. See a high-resolution version on Datashare 45, www.aapg.org/datashare.

toward the northeast develop as a combined effect: (1) increasing negative dynamic topography in the Alpine Tethys region from the increasing age of the reconstructed sea floor from the Late Cretaceous (Figure 1); (2) northeastward movement of Arabia toward and over a high-seismic velocity anomaly presently located between 300 and $800 \mathrm{~km}(186$ and $497 \mathrm{mi}$ ) below easternmost Arabia and Persian
Gulf; and (3) overall uplift of eastern Africa and the Red Sea caused by mantle upwelling associated with the African superplume (Lithgow-Bertelloni and Silver, 1998; Daradich et al., 2003).

Since the Eocene, substantial uplift of eastern and southern Africa is predicted with models that have a smaller ratio between the transition zone and lower mantle viscosities (Figure 4B, model 
Table 3. Relative Importance of Factors Controlling Regional Sea Level

\begin{tabular}{lccc}
\hline Continent & Late Cretaceous & Paleocene-Eocene & Oligocene-Miocene \\
\hline North America & Dynamic + OFA & OFA + Dynamic & OFA (dynamic secondary) \\
Northern Africa, India, and South America & $*$ & $*$ & $*$ \\
Eurasia & OFA $^{* *}$ & OFA & OFA \\
Australia & Dynamic & Dynamic & Dynamic \\
\hline
\end{tabular}

*The interpretation is complicated by unknown paleotopography and/or difference in paleogeographic reconstructions.

**Subduction-related dynamic subsidence might be important in the Alpine Tethys region.

${ }^{\dagger}$ OFA $=$ ocean floor age.
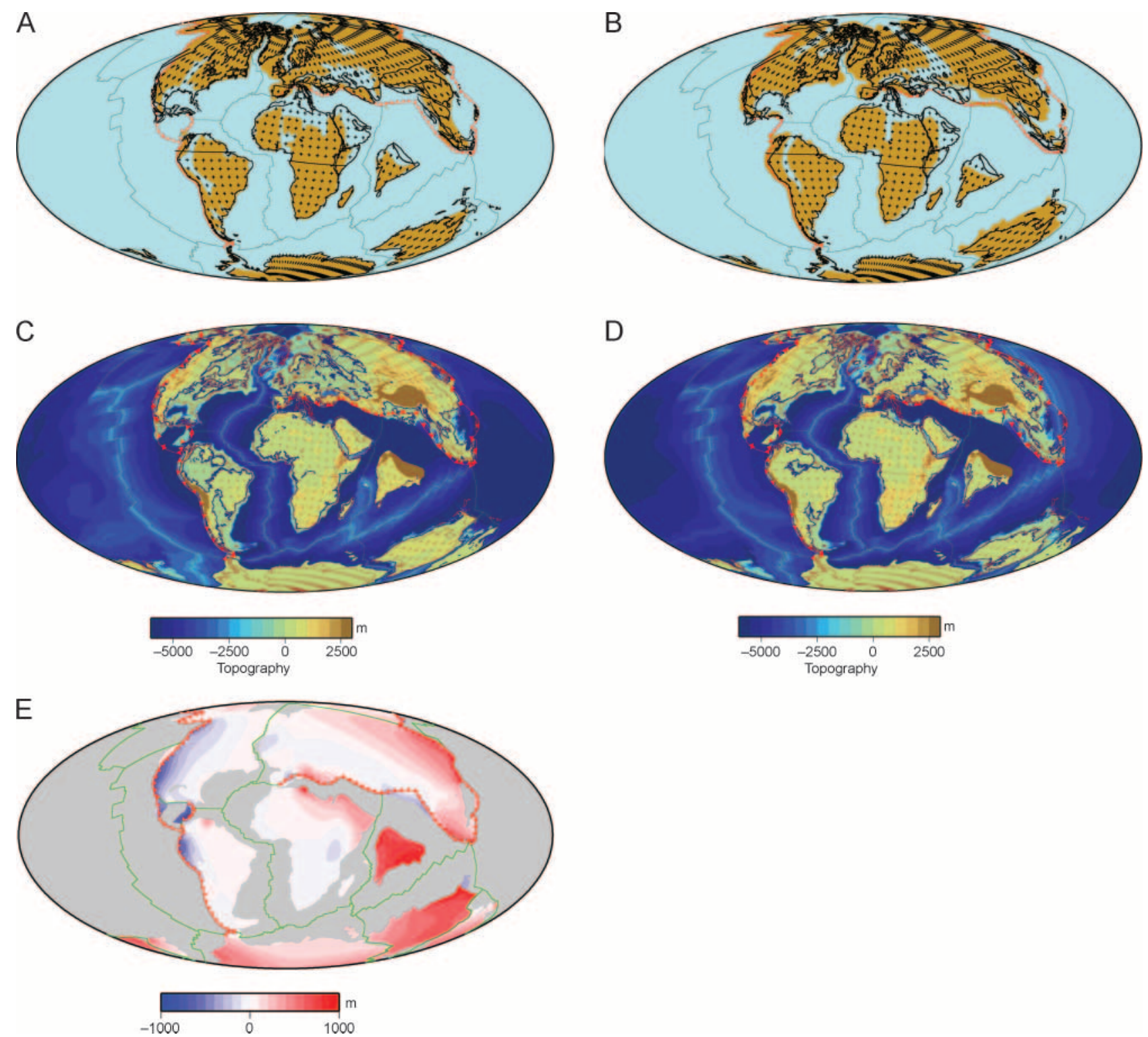

Figure 7. Early Cenozoic global sea level predictions. Paleogeographic reconstructions at $60 \mathrm{Ma}$ (A) (Smith et al., 1994) and $65 \mathrm{Ma}$ (B) (Blakey, 2010), showing reconstructed marine regions in light blue and land regions in brown. (C) DYN-OFA flooding predictions (60 Ma) accounting for the changing age of the ocean floor, dynamic topography, and the geoid and using model M3 (Table 2). (D) OFA flooding predictions $(60 \mathrm{Ma})$ accounting only for the changing age of the ocean floor using the half-space model without flattening (Parsons and Sclater, 1977). (E) Difference between dynamic topography in the past (60 Ma) and present-day predicted dynamic topography for model M3. The dark blue lines on panels $C$ and D show a predicted shoreline. See a high-resolution version on Datashare 45, www.aapg.org/datashare. 

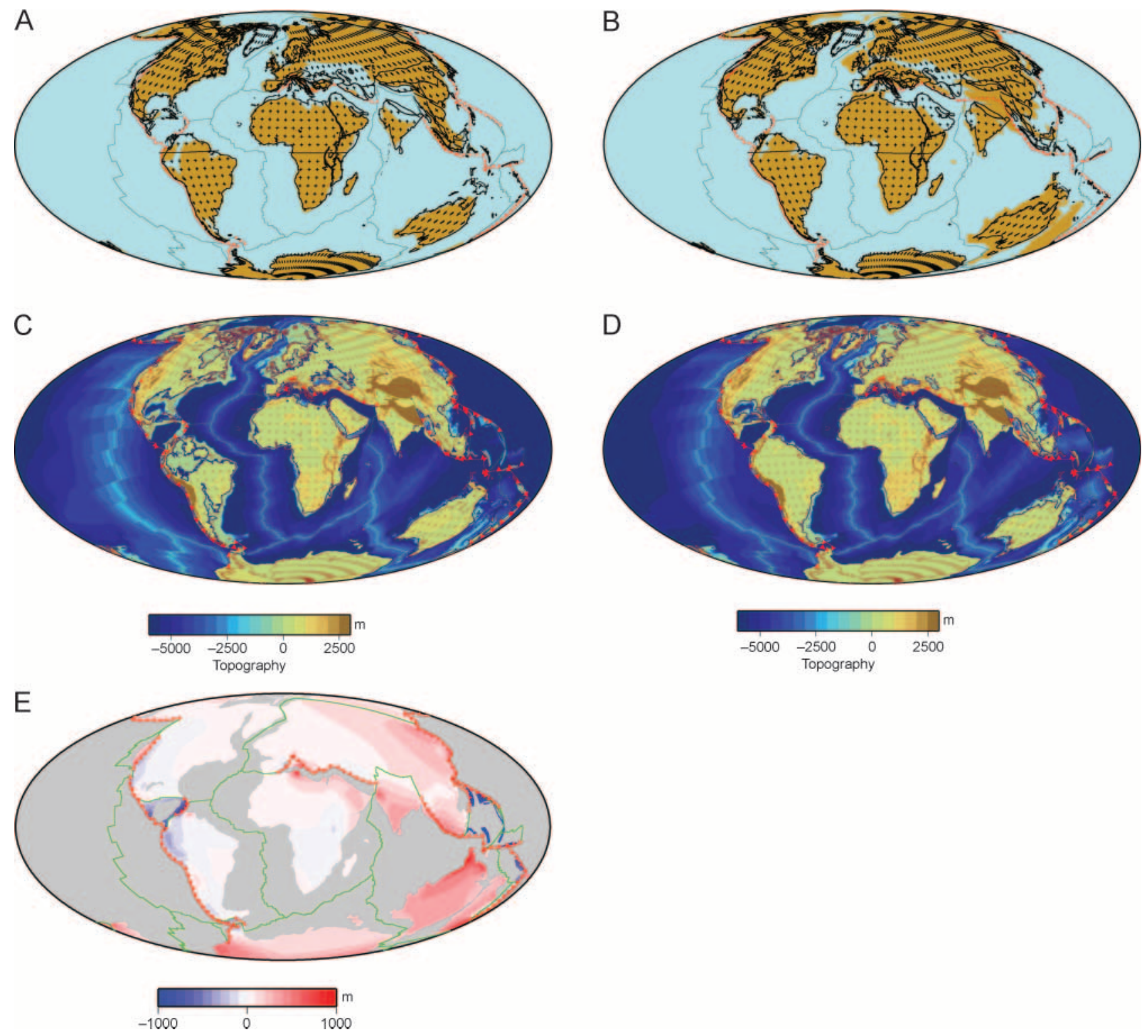

Figure 8. Global sea level predictions (30 Ma). Paleogeographic reconstructions at $30 \mathrm{Ma}$ (A) (Smith et al., 1994) and $35 \mathrm{Ma}$ (B) (Blakey, 2010), showing reconstructed marine regions in light blue and land regions in brown. (C) DYN-OFA flooding predictions (30 Ma) accounting for the changing age of the sea floor, dynamic topography, and the geoid and using model M3 (Table 2). (D) OFA flooding predictions (30 Ma) accounting only for the changing age of the sea floor using the half-space model without flattening (Parsons and Sclater, 1977). (E) Difference between dynamic topography in the past (30 Ma) and present-day predicted dynamic topography for model M3. The dark blue lines on panels $C$ and D show a predicted shoreline. See a high-resolution version on Datashare 45, www.aapg.org/datashare.

M1; Appendix 3, see AAPG Datashare 45 at www .aapg.org/datashare), related to the upwelling of low-density material in the lower mantle below Africa (e.g., Lithgow-Bertelloni and Silver, 1998; Gurnis et al., 2000a). The uplift of eastern Africa occurs continuously from the late Eocene to the present (Appendix 3), and the uplift in southern Africa mostly develops in the last 20 m.y. The computed southward progression of the African uplift is consistent with geologic studies that suggest that southern Africa experienced Miocene uplift (Partridge and Maud, 1987), whereas the uplift and rifting in eastern Africa initiated earlier, between 20 and $30 \mathrm{Ma}$ (Burke, 1996).

The flooding for the entire period since the Late Cretaceous is underpredicted using both OFA and DYN-OFA calculations (Figures 6-8), which we think is at least partially a result of significant change 
in continental isostatic topography, which is not accounted for by our method because the overall uplift of Africa occurs at least since the Eocene (Bond, 1979; Gurnis et al., 2000a). The onset of basin inversion and folding, related to the collision of AfricanArabian and Eurasian plates, initiated in the late Santonian, affecting both northern African-Arabian plate margin and central African rifts (Guiraud and Bosworth, 1997; Guiraud et al., 2005). A brief compressional phase around the end of the Cretaceous and a major plate-scale compression in the early late Eocene (Guiraud et al., 2005) have both strongly affected the development of topography in the region. As the flooding predictions are complicated by unknown isostatic changes, we do not further consider the relative importance of sea level change factors for northern Africa (Table 3).

\section{Eurasia}

In western Siberia and the Alpine Tethys region, a transgression in the Cretaceous (Figure 4C) followed by an overall regression in the Cenozoic (Figure 5C) was observed, equivalent to expected global sea level trends. Cretaceous differential dynamic topography (Figure 4C) ranges from subsidence on the order of 100 to $200 \mathrm{~m}(328-656 \mathrm{ft})$ (model Ml) to neutral values (model M6) over a large part of Eurasia, suggesting an absence of or a little dynamic control on vertical motions (Table 2). Similar to the observed trends, the Alpine Tethys region is predicted to have high-amplitude dynamic subsidence (Figure 4C), related to the increasing age of subducted oceanic lithosphere (Figure 1). The region of Southeast and eastern Asia is predicted to experience overall uplift, related to a decreasing age of the subducted oceanic lithosphere in the east and the closing of the easternmost part of the Tethys Sea by early Cenozoic in the south (Figure 1). For the eastern Asia margin, the eventual total consumption of the Izanagi plate by $60 \mathrm{Ma}$ is observed (Figure 1) (Whittaker et al., 2011), resulting in a progressive subduction of younger sea floor. During the Cenozoic, models predict subsidence in eastern and Southeast Asia and the Alpine Tethys region (Figure 5C), related to the increasing age of subducted oceanic lithosphere (Figure 1). In terms of predicted sea level, OFA models predict well the observed patterns of flooding (Figures 6-8; Table 3), and the introduction of dynamic effects in DYNOFA models does not strongly perturb the inundation. This leads us to suggest that mantle dynamics is secondary in controlling platform flooding (Table 3), with a possible exception of the Alpine Tethys region.

However, more recent geomorphic indicators might indicate a present-day influence of mantle dynamics in Siberia. Analysis of regional incision and lateral shifts of rivers in the West Siberian Basin indicate that it is currently tilting over a long wavelength (Allen and Davies, 2007). The tilting is generally down to the east, away from the Urals and central Asian mountains, toward the Siberian craton. Significant drainage shifts exist in the river systems of the Yenisei, $\mathrm{Ob}$, and Irtysh caused by this long-wavelength tilt of the West Siberian Basin and surroundings (Allen and Davies, 2007). Subtle faulting of the basement, located under the thick basin fill of Mesozoic and lower Cenozoic sediments, has been proposed as a cause of this longwavelength deformation (Allen and Davies, 2007), speculated to potentially be a far-field effect of the India-Eurasia collision (Allen and Davies, 2007). The hybrid models predict overall increasing dynamic subsidence in the general west-to-east direction (Figure 9) for all models, with the total amplitude dependent on the tomography and viscosity. The gradient of differential dynamic topography has the same direction as the inferred direction of tilting from geomorphic analysis (Allen and Davies, 2007) (Figure 9C), and we propose that it is related to the dynamic effects of mantle convection. Two thermal anomalies in the lower mantle (Figure 9C) cause the increasing dynamic subsidence and tilting of the Western Siberian Basin from west to east. A warm upwelling structure is located on the western edge of the basin, causing it to be dynamically higher than the eastern edge of the basin, which is associated with a large, cold mantle downwelling located in the lower mantle.

\section{Southeast Asia}

The Sundaland core was subaerially exposed during the late Oligocene but was significantly flooded by the middle Miocene (Hall and Morley, 2004) 
Figure 9. Inferred tilting of the West Siberian Basin based on differential dynamic tomography. Differential dynamic topography for models $M 1$ and $M 3$ in the period 0 to $30 \mathrm{Ma}(\mathrm{A})$ and 0 to $10 \mathrm{Ma}$ (B). (C) East-west cross section (location shown on panel A) showing dynamic topography trends for models $\mathrm{M} 1$ to $\mathrm{M} 6$ (bottom panel), thermal buoyancy field (middle panel), surface-to-core-mantle boundary (CMB) and drainage-shift azimuth directions (Allen and Davies, 2007) (top panel; azimuth is shown in $60^{\circ}$ bins with respect to north).
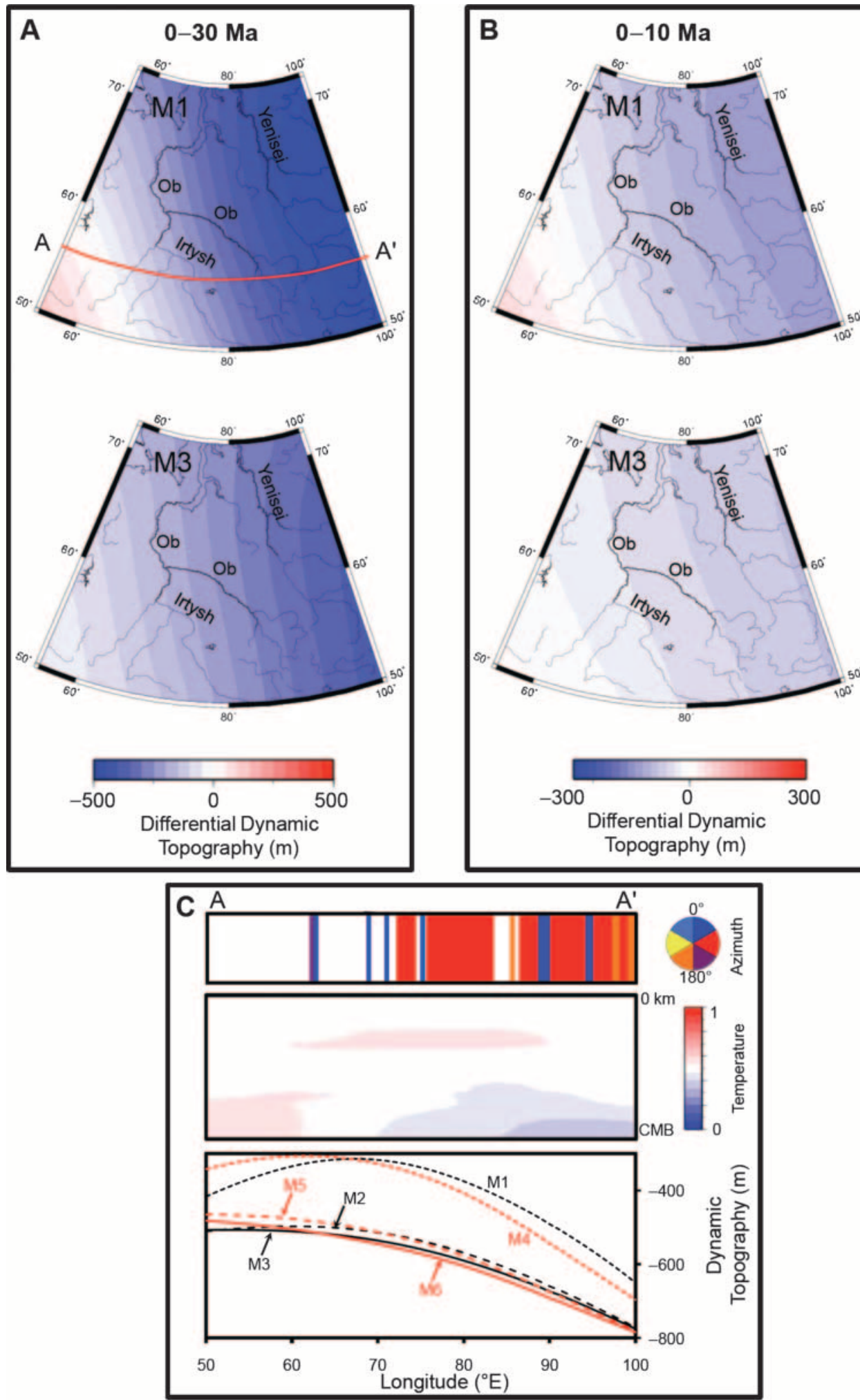

(Figure 5D). Dynamic earth models predict an overall dynamic subsidence within the southern part of Sundaland and Borneo (Figure 5D; Table 2). A large, fast-seismic velocity anomaly exists below Southeast Asia between 400 and 1200 km (249 and $746 \mathrm{mi}$ ) (Masters et al., 2000; Ritsema et al., 
2004). As the mantle flow is reversed in SBI, this anomaly rises upward, with a large part located within the upper mantle in the Eocene, resulting in predicted dynamic subsidence. Integrated forward, dynamic earth models suggest that Southeast Asia experienced an event similar to a mantle avalanche, when a significant part of subducting slabs penetrated into the lower mantle, resulting in a significantly increased dynamic topography low, potentially causing observed marine transgression. The predicted amplitudes of subsidence are dependent on tomography and viscosity and have amplitudes up to $500 \mathrm{~m}(1640 \mathrm{ft})$ within $1500 \mathrm{~km}$ (932 $\mathrm{mi}$ ) of the subduction zones (Figure 5D), whereas higher subsidence amplitudes are predicted along the subduction zone itself. The wavelength of predicted dynamic subsidence is much larger than that associated with the anomalous Sundaland basins. These basins have relatively small widths and postrift sedimentary sequences, with thicknesses up to $12 \mathrm{~km}$ (7 mi) (Hall and Morley, 2004; Morley and Westaway, 2006), so that processes beyond simple rifting must be invoked to explain their formation. The amplitude of predicted dynamic subsidence in the Sundaland interior (Figure 5D) has a similar magnitude as the dynamic subsidence estimated based on borehole subsidence in Southeast Asia (Wheeler and White, 2002), suggesting that dynamic topography might have had an important influence on subsidence and overall flooding during the Neogene, affecting the evolution of hydrocarbon reservoirs in the region. The zone of predicted dynamic subsidence is relatively well correlated with the zone of inferred Sundaland flooding. However, we predict that Borneo and Java subsided, opposite to their inferred trends, which suggests that vertical motions are controlled by more regional tectonics in this region. We propose that dynamic subsidence between 30 and $10 \mathrm{Ma}$ might be contributing to the overall platform drowning between the late Oligocene and middle Miocene.

\section{South America}

In South America, a north-south-trending interior seaway developed between 90 and $50 \mathrm{Ma}$ (Figure 4D), with a relative stability of the inundated region in the early Cenozoic (Blakey, 2010).
Dynamic earth models predict a region of Late Cretaceous dynamic subsidence in western South America, with amplitudes from 100 to $500 \mathrm{~m}$ (328-1640 ft) (Figure 4D; Table 2) and a wavelength larger than one inferred paleogeographically. Although the development of the South America Interior seaway has been previously related to flexural loading by the Andes (Hoorn et al., 1995), we postulate that a component resulting from increasing dynamic topography may also exist (Figure 6D).

Global Cenozoic paleogeographic reconstructions imply relatively isolated regions of vertical motions in the north and northeast (Figure 5E), with most of South America being stable. However, more regionally focused studies indicate that central Patagonia has been experiencing Neogene uplift (Guillaume et al., 2009) and that the interior Pebas Sea developed in the Miocene (Hoorn et al., 1995; Shepard et al., 2010) (Figure 5E). Dynamic earth models indicate the overall Neogene uplift of Patagonia, concentrated in the central Patagonian Basin in the last 20 m.y. (Figure 5E; Table 2). From the Cretaceous to Cenozoic, subsidence migrated eastward in the plate frame and is concentrated in the northern part of central South America in the last 20 m.y. for model Ml (Figure 5E). The continuous dynamic uplift of the Andes and western South America emerge from the models for the last 20 m.y. (Figure 5E; Table 2).

The observed pattern of the eastward migration of subsidence from the Late Cretaceous to the present is related to the geometry of the subducting Farallon (Nazca slab). Currently, the slab is imaged as a continuous structure in seismic tomography up to mid-mantle depths under the whole of South America. As the plate motions and mantle flow are reversed in an SBI from $0 \mathrm{Ma}$ to the Late Cretaceous, the high-density material moves upward, and it is located under western South America in the Late Cretaceous, which causes subsidence. The modeled pattern of vertical motions associated with the subducting slab below South America is equivalent to the scenario described for North America.

Late Cretaceous and Paleocene flooding are overpredicted, caused by the relatively low isostatic topography of South America in the flooded 
regions (Figures 6, 7). This might imply that the isostatic topography of South America has changed since the Late Cretaceous and that the continent has experienced overall subsidence. This putative subsidence could be attributed to active subduction, which creates a progressive dynamic topography low in South America (Appendix 2). Flooding at $30 \mathrm{Ma}$ is best predicted by OFA models (Figure 8), whereas the inclusion of dynamic effects in DYN-OFA models overpredicts flooding. However, if more regional reconstructions (e.g., Hoorn, 1996) including those that include the interior Pebas Sea are considered, the DYN-OFA predictions yield a better match to the observations. The dynamics of Farallon (more recently Nazca) plate subduction might have controlled the Miocene switch in the direction of the Amazon River at $11 \mathrm{Ma}$ (Shepard et al., 2010). A similar outcome emerges from our DEMs, but more detailed stratigraphic data and paleogeographic information are needed to clarify the link.

\section{Australia}

Australia was significantly more subaerial during the Cretaceous than now, remaining high from the Late Cretaceous until early Cenozoic (Figure 4E). The models predict an overall neutral to positive dynamic topography change from 80 to $60 \mathrm{Ma}$ (Figure 4E). Modeled dynamic uplift is consistent with the movement of Australia away from a subducted Gondwanaland slab, as it was previously proposed (Gurnis et al., 1998; Gurnis et al., 2000b). Australia experienced an overall marine transgression over a large part of the Cenozoic (Figure 5F). Dynamic models predict an overall dynamic subsidence over the Cenozoic (Figure 5F; Table 2), increasing from south-southwest to north-northeast, causing an overall tilt of Australia. The Cenozoic tilt has been inferred from a detailed study of paleoshorelines (Sandiford, 2007; DiCaprio et al., 2009) and was also previously attributed to the dynamic topography and geoid (Sandiford, 2007) and dynamic topography low resulting from developing subduction zones toward the north and east (DiCaprio et al., 2009; DiCaprio et al., 2010). Dynamic earth models support the findings of
DiCaprio et al. (2009) and DiCaprio et al. (2010) showing that dynamic subsidence is caused by the development of subduction zones in the surrounding regions. In terms of prediction of sea level in the Late Cretaceous and early Cenozoic (Figures 6, 7), DYN-OFA models yield predictions more similar to the observations, suggesting that dynamics are important in controlling the regional sea level in Australia (Table 3).

\section{Global Sea Level Estimates}

With the volume of ocean water assumed constant for over millions of years, global sea level on geologic time scales results from a change of ocean bathymetry caused by variations in ocean floor age, dynamic topography in oceanic and flooded continental areas, emplacement of oceanic plateaus, and sedimentation. The predicted global sea level by DEMs shows an overall decrease from the Late Cretaceous to the present, with a maximum at $80 \mathrm{Ma}$ (Figure 10). The predicted sea level fall amplitude from changing ocean floor age ranges significantly between 304 and $528 \mathrm{~m}$ (997 and $1732 \mathrm{ft}$ ) for different cooling models (Figure 10A); a half space without flattening (OFA-HS) gives the largest prediction, whereas global depth and heat flow model $(\mathrm{GDH})$ gives the smallest. The sea level decrease from OFA is caused by the deepening of bathymetry from the aging sea floor from the Late Cretaceous to the present day (Figure 1), as discussed previously (e.g., Kominz, 1984; Kominz et al., 2008; Müller et al., 2008a). In isolation, changing dynamic topography in oceanic regions causes a sea level rise since the Late Cretaceous, with amplitudes between 100 and $200 \mathrm{~m} \mathrm{(328} \mathrm{and}$ $656 \mathrm{ft}$ ) (Figure 10A). The contribution of dynamic topography in the flooded continental areas is much smaller than that in the oceanic regions, having maximum amplitudes from -10 to $80 \mathrm{~m}(-33-$ $262 \mathrm{ft}$ ) (Figure 10A) of sea level rise. The amplitudes of dynamic topography contributions are the largest at $70 \mathrm{Ma}$, and they significantly decrease during the Cenozoic (Figure 10A). The dynamic topography contribution to global sea level in oceanic regions is mostly driven by positive dynamic 

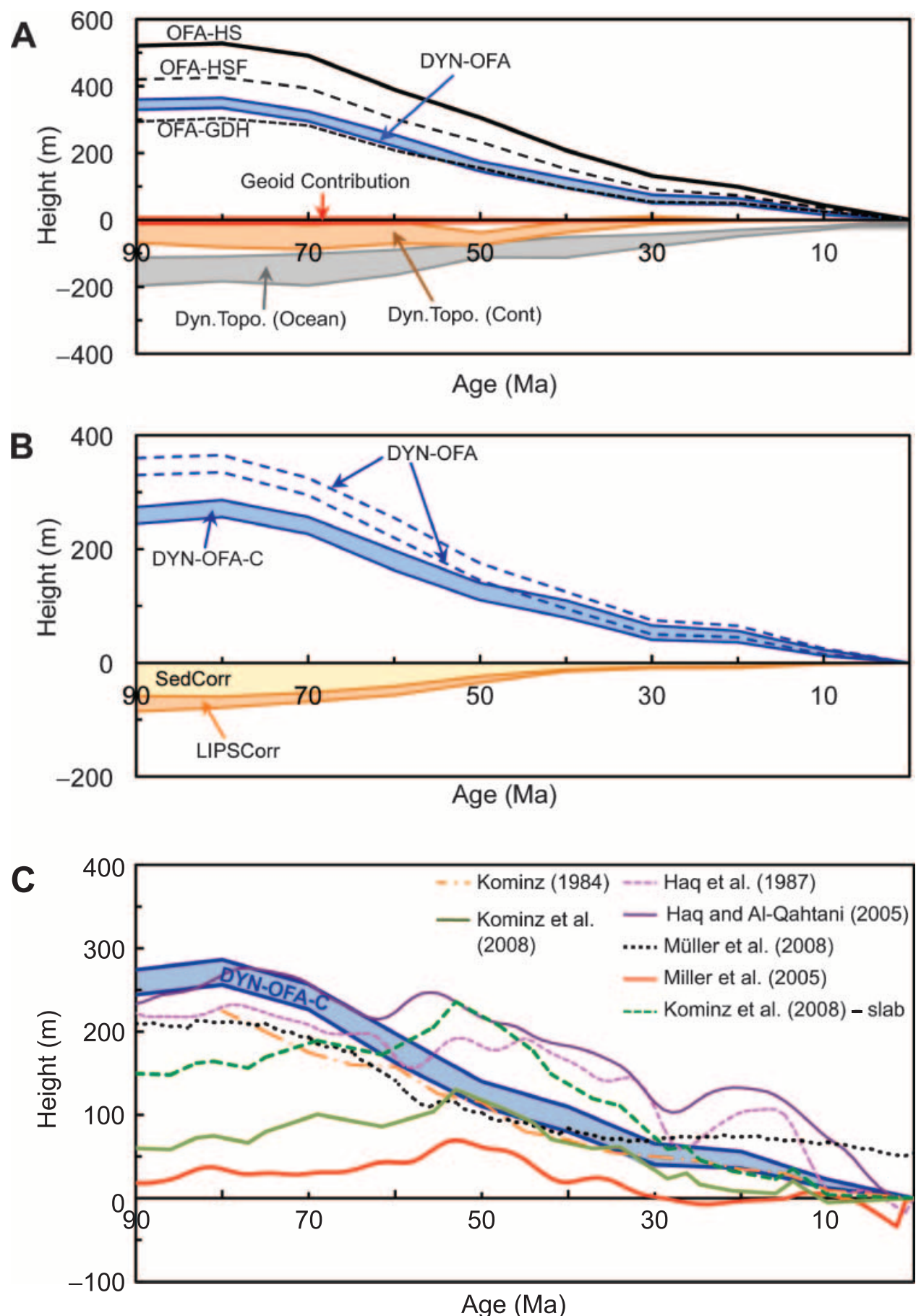

Figure 10. Global sea level predictions. (A) Predictions accounting for the changing age of the sea floor using half-space (OFA-HS), half-space model with flattening (OFA-HSF), and global depth and heat flow (GDH)-1 model (OFA-GDH), and DYNOFA models accounting for the changing age of the sea floor, dynamic topography, and geoid. The blue area shows the range of sea level values estimated from DYN-OFA models. The gray, orange, and red areas show the range of dynamic topography in oceanic areas, dynamic topography in flooded continental areas, and geoid contribution to global sea level, respectively. (B) Final predictions of sea level from DYN-OFA models (blue area; DYN-OFA-C) accounting for corrections resulting from sedimentations (yellow area; SedCorr) and emplacement of large igneous provinces (orange area; LIPSCorr). (C) Comparison between the final prediction of sea level from DYN-OFA-C models (blue area) and previously published sea level curves. Dyn. Topo. $=$ dynamic topography; Dyn. Topo. (Cont.) = dynamic topography (continents); SedCorr. = sediment correction; LIPSCorr = correction for large igneous provinces emplacement. topography from low-density mantle upwellings. As low-density anomalies rise from the Late Cretaceous to the present, the amplitude of dynamic topography increases, resulting in sea level rise, which offsets overall sea level fall associated with the increasing age of the sea floor (Figure 10A). The contribution of high-density downwelling anomalies in the oceanic regions to the overall sea level change is less significant because the regions of dynamic topography lows in the oceans are much more spatially limited (Appendix 2). The contribution of dynamic topography in the flooded continental regions is mostly driven by dynamic topography lows, which have an overall increasing mean amplitude (Figure 10A). 
The contribution of the geoid to global sea level is much smaller than that from dynamic topography (Figure 10A) because the ratio between geoid and topography is small (Figure 2).

Therefore, the sea level estimates for DYNOFA models, before accounting for sedimentation and oceanic plateau emplacement, have maximum amplitudes at $80 \mathrm{Ma}$ between 330 and $365 \mathrm{~m}$ (1083 and $1198 \mathrm{ft}$ ) (Figure 10A) for the six DEMs. The predicted range of dynamic sea level for DYNOFA models lies between the predictions for the two cooling models that include flattening (Figure 10A; OFA-HSF, OFA-GDH). This is not unexpected if dynamic topography is the ultimate cause for the flattening of the old sea floor, empirically included in the age-to-depth relationships for OFA-HSF and OFA-GDH. Sedimentation and emplacement of large igneous provinces result in an overall sea level rise from the Late Cretaceous to the present (Müller et al., 2008b). Maximum amplitudes of sea level change caused by sedimentation and igneous provinces are much smaller at 60 and $27 \mathrm{~m} \mathrm{(197} \mathrm{and}$ $89 \mathrm{ft}$ ), respectively, so that the combined effect of all of the processes still results in an overall fall with a maximum amplitude of up to $286 \mathrm{~m}(938 \mathrm{ft}$ ) since the Late Cretaceous (Figure 10B; DYN-OFAC). The DYN-OFA-C global sea level is within the range of those previously proposed (Figure 10C).

\section{DISCUSSION}

We use DEMs to better understand regional and global sea levels from the Late Cretaceous. We find that oceanic regions, on average, have a positive $d y-$ namic topography, which increased from the Late Cretaceous to the present because of the overall rise of low-density upwelling anomalies, resulting in a sea level rise, with the estimated amplitude ranging between 100 and $200 \mathrm{~m}$ (328 and $656 \mathrm{ft}$ ) in the last 90 m.y. (Figure 10). Conrad and Husson (2009) use forward convection models to estimate Cenozoic sea level change caused by a sea floor dynamic

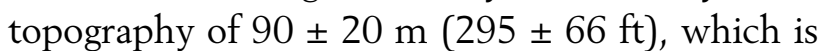
similar to the estimated amplitudes in DEMs of 90 to $140 \mathrm{~m}(295-459 \mathrm{ft})$ of sea level change in the last 60 m.y. We also find that dynamic topography in flooded continental areas has contributed to sea level change by introducing up to $80 \mathrm{~m} \mathrm{(262} \mathrm{ft)} \mathrm{of} \mathrm{sea}$ level rise since the Late Cretaceous (Figure 10). Conrad and Husson (2009) also find that dynamic topography in continental areas has an effect on sea level, in which the rate of change is more than three times smaller than the one caused by oceanic dynamic topography. The sea level rise caused by dynamic topography, along with the rise resulting from the emplacement of oceanic plateaus and sedimentation, partially offsets the larger amplitude sea level fall because of increases in OFA (Figure 10). The overall fall of the sea level caused by the change in OFA and spreading-ridge crustal production are mostly driven by changes in the Pacific Ocean, as the largest drop in the global crustal production of approximately $50 \%$ occured between 65 and $60 \mathrm{Ma}$, caused by the subduction of the Izanagi-Pacific spreading ridge (Müller et al., 2008b) (Figure 1) and followed by a subsequent ridge subduction beneath the Americas (Müller et al., 2008b).

When calculating sea level amplitudes, we prefer to use the half-space cooling model so as not to double count the effect of sea floor flattening (Kido and Seno, 1994), which can arise when dynamic topography is considered from a mantle flow model (Müller et al., 2008b). However, if we implemented cooling models that include flattening (e.g., OFAHSF and OFA-GDH), the final sea level would have the same trend but with a significantly smaller amplitude (Figure 10A). We predict the total global sea level fall from the Late Cretaceous, with a maximum amplitude of up to $286 \mathrm{~m}(938 \mathrm{ft})$ reached at $80 \mathrm{Ma}$. Late Cretaceous sea levels are on the high end of previous estimates (Figure 10C) (Watts and Steckler, 1979; Kominz, 1984; Haq et al., 1987; Haq and Al-Qahtani, 2005; Miller et al., 2005; Kominz et al., 2008; Müller et al., 2008b), with the values being similar to the ones inferred by $\mathrm{Haq}$ and Al-Qahtani (2005). During the Cenozoic, the proposed sea levels were generally lower than the ones derived using the global correlation of stratigraphic sequences (Watts and Steckler, 1979; Haq and AlQahtani, 2005) but higher than the ones derived based on the backstripping of sedimentary sections at five boreholes located on the New Jersey coastal plain (Miller et al., 2005) and within the range of 
other studies (Figure 10C). Our study demonstrates the importance of accounting for the effects of dynamic topography when calculating global sea level, but the actual amplitudes should be more constrained when more comprehensive stratigraphic and geologic constraints are used in the future.

Whereas positive dynamic topography associated with mantle upwellings represents the main dynamic factor controlling global sea level, the dynamic topography associated with subducting or previously subducted slabs is also an important factor that controls the pattern of continental flooding and relative vertical motion and impacts several regions with important hydrocarbon accumulations. We find that the Farallon slab in North America creates a dynamic topography low that controls Cretaceous flooding and subsidence in the WIS, similar to previous inverse models (Liu et al., 2008; Spasojevic et al., 2009). As North America moves westward and the Farallon slab sinks into the lower mantle during Cenozoic, the Western Interior experiences a dynamic uplift and eastern North America experiences an overall subsidence. The Farallon and Nazca plates continuously subduct in South America, contributing to an interior flooding developed from 90 to $50 \mathrm{Ma}$ and potentially contributing to a Miocene switch in the direction of drainage from a predominantly northward direction to a formation of the eastwarddraining Amazon River (Shepard et al., 2010), and affecting the evolution of petroleum systems of the Atlantic margin of South America. Subduction in the Alpine Tethys region causes an overall subsidence and flooding of the Mediterranean region and a Cenozoic dynamic subsidence and flooding of northern Africa and Arabia. A mantle-avalanche-type event in Southeast Asia between the late Oligocene and the Miocene resulted in the dynamic subsidence and potential drowning of Sundaland. Development of subduction zones north and east from Australia contributes to an overall tilting toward north-northeast that potentially explains discrepancies between Australian and global sea levels during the Cenozoic, as previously found (DiCaprio et al., 2009; DiCaprio et al., 2010).

In the Cenozoic, we find that mantle upwelling anomalies have had a relatively limited effect on the pattern of the large-scale vertical motion of continents and regional sea level for most continents except Africa. The African superplume has caused an uplift in eastern and southern Africa since the Eocene, and it contributes to the Cenozoic tilting down to north-northeast of Arabia. Mid- and lower mantle upwelling located to the west of the Siberian Basin, and adjacent to the east Siberian, lower mantle downwelling, resulting in the west-east tilting of Siberia that potentially results in the shifting of drainage patterns in this region.

Sea level predictions are affected by some underlying assumptions: (1) time-invariant isostatic topography, (2) the neglect of continental margin extension, and (3) constant ocean volume used in sea level calculations. First, since paleoelevation represents one of the most difficult variables to reconstruct from the geologic record (Garzione et al., 2008), and detailed maps of the past global topography have yet to be assembled, we use presentday topography rotated with plate motions and corrected for dynamic topography. As crustal columns experienced significant changes resulting from orogeny, such as the Laramide, Andean, Alpine, and Himalayan orogenies (Spencer, 1974; Saleeby, 2003; English and Johnston, 2004; Ghosh et al., 2006), the quality of sea level predictions is significantly affected in orogenic regions. Second, because continental margin extension has been estimated to result in approximately $20 \mathrm{~m}(\sim 66 \mathrm{ft})$ of sea level change since the beginning of Pangea breakup (Kirschner et al., 2010), significantly smaller than the overall sea level change (Figure 10), its neglect is reasonable. Third, we assume constant water volume, as we examine sea level changes at time scales greater than $1 \mathrm{~m}$.y., which is longer than the ocean volume fluctuations from glacial cycles occurring on time scales of hundreds of thousands of years or shorter (Kominz, 2001).

The main limitations of the current method are the use of a single, average vertical viscosity structure and seismic velocity-to-density scaling; the treatment of subduction zones; the use of one paleogeographic reconstruction; and the limited assimilation of stratigraphic data. A significant uncertainty remains regarding the viscosity profile of 
the mantle, with suggestions that significant differences might exist between viscosity structures in different regions (e.g., Liu et al., 2008; Schellart et al., 2009; Spasojevic et al., 2010a) or that the mantle, on average, might have the same vertical viscosity profile (e.g., van der Meer et al., 2010). A single seismic velocity-to-density scaling, devised from the fit to global geoid (Spasojevic et al., 2010) is used for all models, although it was suggested that the 3-D velocity-to-density scaling model, which might differ for upwelling and downwelling anomalies (Forte, 2007; Simmons et al., 2009), might be more appropriate. As both viscosity structure and velocity-to-density scaling influence dynamic topography, and in turn sea level estimates, in the future, it would be important to test the sensitivity of regional and global sea levels to the variations of these parameters. Definition of subduction zones in the models can be improved by introducing much higher resolution, variable viscosity slabs, and surrounding mantle wedges, possibly implementing methods at ultra-high resolution (1 km [0.6 mi] where needed) (Stadler et al., 2010), and introducing a more realistic treatment of diffusion in an adjoint solution to the equations instead of the current SBI (Liu and Gurnis, 2008). The importance of strong viscosity variations has been demonstrated in the regional models of the TongaKermadec and Aleutian subduction zones (Billen et al., 2003; Billen and Gurnis, 2001), which show that significant lateral viscosity variations are required between upper mantle slabs and adjacent mantle wedges to match the geoid, dynamic topography, and stress patterns in subduction zones, whereas strong slabs also give rise to a better match to observed present-day plate motions (Stadler et al., 2010). It has been shown that the use of different reconstructions in the west Pacific has substantially affected sea level estimates since the Cenozoic (Xu et al., 2006); in the future, one can test alternative paleogeographic reconstructions and their effect on patterns of vertical motions and relative and global sea levels. Inclusion of more stratigraphic data, including more comprehensive borehole data, sediment isopach maps, and detailed regional paleoshoreline reconstructions, might impose better constraints on the history of the vertical motion of continents and enable us to infer mantle viscosity structure on a finer scale.

\section{CONCLUSIONS}

We present the results of DEMs that combine inverse and forward methods for solving for mantle convection and assimilate plate tectonic reconstructions into mantle convection models with vertically and laterally varying viscosity. We self-consistently account for the changing age of the sea floor, dynamic topography, and the geoid, with the goal to better understand the vertical motion of continents and the regional and global sea levels. We find that both the changing age of the ocean floor and dynamic topography represent important factors controlling sea level. Predicted sea level shows an overall fall from the Late Cretaceous to the present, with a maximum amplitude of $286 \mathrm{~m}(938 \mathrm{ft})$ at $80 \mathrm{Ma}$. The largest contribution to the sea level fall comes from the reduced oceanic crust production from the Late Cretaceous to the present, inferred from ocean age grids. The dynamic topography in oceans and flooded continental regions result in sea level rise, with maximum amplitudes varying between 100 and $200 \mathrm{~m}$ (328 and $656 \mathrm{ft})$ and -10 and $80 \mathrm{~m} \mathrm{(-33}$ and $262 \mathrm{ft}$ ), respectively, reducing the overall amplitude of sea level fall inferred from age grids. The movement of continents with respect to large-scale dynamic topography causes the dynamic subsidence and uplift of continents, controls regional sea level, and affects the hydrocarbon basins for North America and South America from the Late Cretaceous to the present, Australia during the Cenozoic, and North Africa and Arabia since the Eocene. Eastern and South Africa uplift dynamically in the last 20 to 30 m.y., whereas Siberia and Australia experience Cenozoic tilting.

\section{REFERENCES CITED}

Allen, M. B., and C. E. Davies, 2007, Unstable Asia: Active deformation of Siberia revealed by drainage shifts: Basin Research, v. 19, p. 379-392, doi:10.1111/j.1365-2117 .2007.00331.x.

Billen, M. I., and M. Gurnis, 2001, A low-viscosity wedge in 
subduction zones: Earth and Planetary Science Letters, v. 193, no. 1-2, p. 227-236, doi:10.1016/S0012-821X (01)00482-4.

Billen, M. I., M. Gurnis, and M. Simons, 2003, Multiscale dynamics of the Tonga-Kermadec subduction zone: Geophysical Journal International, v. 153, no. 2, p. 359388, doi:10.1046/j.1365-246X.2003.01915.x.

Bird, P., 1998, Kinematic history of the Laramide orogeny in latitudes 35 to $49^{\circ} \mathrm{N}$, western United States: Tectonics, v. 17 , no. 5, p. 780-801, doi:10.1029/98TC02698.

Blakey, R., 2008, Gondwana paleogeography from assembly to breakup: A 500-m.y. odyssey, in C. R. Fielding, T. D. Frank, and J. L. Isbell, eds., Resolving the late Paleozoic ice age in time and space, p. 1-28.

Blakey, R., 2010, Global paleogeographic maps: http://jan .ucc.nau.edu/ rcb7/globaltext2.html (accessed March 2010).

Bond, G., 1976, Evidence for continental subsidence in North America during Late Cretaceous global submergence: Geology, v. 4, no. 9, p. 557-560, doi:10.1130/0091 -7613(1976)4<557:EFCSIN>2.0.CO;2.

Bond, G. C., 1979, Evidence for some uplifts of large magnitude in continental platforms: Tectonophysics, v. 61, no. 1-3, p. 285-305, doi:10.1016/0040-1951(79) 90302-0.

Boyden, J. A., R. D. Muller, M. Gurnis, T. H. Torsvik, J. A. Clark, M. Turner, H. Ivey-Law, R. J. Watson, and J. S. Cannon, 2011, Next-generation plate-tectonic reconstructions using GPlates, in G. R. Keller and C. Baru, eds., Geoinformatics: Cyberinfrastructure for the solid earth sciences: United Kingdom, Cambridge University Press, p. 95-113.

Burgess, P. M., M. Gurnis, and L. Moresi, 1997, Formation of sequences in the cratonic interior of North America by interaction between mantle, eustatic, and stratigraphic processes: Geological Society of America Bulletin, v. 109, no. 12, p. 1515-1535, doi:10.1130/0016-7606(1997) 109<1515:FOSITC>2.3.CO;2.

Burke, K., 1996, The African plate: South African Journal of Geology, v. 99, p. 341-409.

Conrad, C. P., and M. Gurnis, 2003, Seismic tomography, surface uplift, and the breakup of Gondwanaland: Integrating mantle convection backwards in time: Geochemistry, Geophysics, Geosystems, v. 4, no. 3, p. 1031, doi:10.1029/2001GC000299.

Conrad, C. P., and L. Husson, 2009, Influence of dynamic topography on sea level and its rate of change: Lithosphere, v. 1, no. 2, p. 110-120, doi:10.1130/L32.1.

Cook, T. D., and A. W. Bally, 1975, Stratigraphic atlas of North and Central America: Princeton, New Jersey, Princeton University Press, $272 \mathrm{p}$.

Daradich, A., J. X. Mitrovica, R. N. Pysklywec, S. D. Willett, and A. M. Forte, 2003, Mantle flow, dynamic topography, and rift-flank uplift of Arabia: Geology, v. 31, no. 10, p. 901-904, doi:10.1130/G19661.1.

DiCaprio, L., M. Gurnis, and R. D. Muller, 2009, Longwavelength tilting of the Australian continent since the Late Cretaceous: Earth and Planetary Science Letters, v. 278 , no. $3-4$, p. $175-185$, doi:10.1016/j.epsl.2008 .11 .030 .
DiCaprio, L., M. Gurnis, R. D. Muller, and E. Tan, 2010, Mantle dynamics of continent-wide Cenozoic subsidence and tilting of Australia: Lithosphere, v. 3, p. 311-316, doi:10.1130/L140.1.

English, J. M., and S. T. Johnston, 2004, The Laramide orogeny: What were the driving forces?: International Geology Review, v. 46, no. 9, p. 833-838, doi:10.2747/0020 $-6814.46 .9 .833$.

Forte, A. M., 2007, Constraints on seismic models from other disciplines: Implications for mantle dynamics and composition, in B. Romanowicz and A. M. Dziewonski, eds., Treatise of geophysics: Amsterdam, Elsevier, p. 805854.

Garzione, C. N., G. D. Hoke, J. C. Libarkin, S. Withers, B. MacFadden, J. Eiler, P. Ghosh, and A. Mulch, 2008, Rise of the Andes: Science, v. 320, no. 5881, p. 13041307, doi:10.1126/science.1148615.

Ghosh, P., C. N. Garzione, and J. M. Eiler, 2006, Rapid uplift of the Altiplano revealed through $\mathrm{Cl3}-\mathrm{O} 18$ bonds in paleosol carbonates: Science, v. 311, no. 5760, p. 511-515, doi:10.1126/science.1119365.

Goes, S., and S. van der Lee, 2002, Thermal structure of the North American uppermost mantle inferred from seismic tomography: Journal of Geophysical Research, v. 107, no. B3, p. 2050, doi:10.1029/2000JB000049.

Grand, S. P., 2002, Mantle shear-wave tomography and the fate of subducted slabs: Philosophical Transactions of the Royal Society of London 360, p. 2475-2491.

Guillaume, B., J. Martinod, L. Husson, M. Roddaz, and R. Riquelme, 2009, Neogene uplift of central eastern Patagonia: Dynamic response to active spreading ridge subduction?, Tectonics, v. 28, p. TC2009, doi:10.1029 /2008TC002324.

Guiraud, R., and W. Bosworth, 1997, Senonian basin inversion and rejuvenation of rifting in Africa and Arabia: Synthesis and implications to plate-scale tectonics: Tectonophysics, v. 282, no. 1-4, p. 39-82, doi:10.1016 /S0040-1951(97)00212-6.

Guiraud, R., W. Bosworth, J. Thierry, and A. Delplanque, 2005, Phanerozoic geological evolution of northern and central Africa: An overview: Journal of African Earth Sciences, v. 43, no. 1-3, p. 83-143, doi:10.1016/j .jafrearsci.2005.07.017.

Gurnis, M., 1990, Bounds on global dynamic topography from Phanerozoic flooding of continental platforms: Nature, v. 344 , no. 6268 , p. $754-756$, doi:10.1038/344754a0.

Gurnis, M., 1993, Phanerozoic marine inundation of continents driven by dynamic topography above subducting slabs: Nature, v. 364 , no. 6438 , p. 589-593, doi:10.1038 /364589a0.

Gurnis, M., R. Müller, and L. Moresi, 1998, Cretaceous vertical motion of Australia and the Australian-Antarctic discordance: Science, v. 279, no. 5356, p. 1499-1504, doi:10.1126/science.279.5356.1499.

Gurnis, M., J. Mitrovica, J. Ritsema, and H. van Heijst, 2000a, Constraining mantle density structure using geological evidence of surface uplift rates: The case of the African superplume: Geochemistry, Geophysics, Geosystems, v. 1, no. 7, p. 1020, doi:10.1029/1999GC000035.

Gurnis, M., L. Moresi, and R. D. Muller, 2000b, Models of 
mantle convection incorporating plate tectonics: The Australian region since the Cretaceous, in M. A. Richards, R. Gordon, and R. van der Hilst, eds., The history and dynamics of global plate motions: Washington, D.C., American Geophysical Union, p. 211-238.

Gurnis, M., M. Turner, S. Zahirovic, L. DiCaprio, S. Spasojevic, R. D. Müller, J. Boyden, M. Seton, V. C. Manea, and D. J. Bower, Plate tectonic reconstructions with continuously closing plates: Computers and Geosciences, 38, p. 35-42.

Hager, B. H., 1984, Subducted slabs and the geoid: Constraints on mantle rheology and flow: Journal of Geophysical Research, v. 89, no. B7, p. 6003-6015, doi:10 .1029/JB089iB07p06003.

Hall, R., and C. K. Morley, 2004, Sundaland basins, in P. Clift, W. Kuhnt, P. Wang, and D. Hayes, eds., Continentocean interactions within East Asian marginal seas: American Geophysical Union, Washington, D.C., American Geophysical Union Geophysical Monograph Series 149, p. 55-85.

Hallam, A., 1992, Phanerozoic sea level changes: New York, Columbia University Press, 266 p.

Haq, B. U., and A. M. Al-Qahtani, 2005, Phanerozoic cycles of sea level change on the Arabian platform: GeoArabia, v. 10, no. 2, p. 127-160.

Haq, B. U., J. Hardenbol, and P. R. Vail, 1987, Chronology of fluctuating sea levels since the Triassic: Science, v. 235, no. 4793, p. 1156-1167.

Hays, J. D., and W. C. Pitman, 1973, Lithospheric plate motions, sea level changes and climatic and ecological consequences: Nature, v. 246, no. 5427, p. 18-22, doi:10 $.1038 / 246018 \mathrm{a} 0$.

Hoorn, C., 1996, Miocene deposits in the Amazonian foreland basin: Science, v. 273, no. 5271, p. 122-123, doi:10 $.1126 /$ science.273.5271.122.

Hoorn, C., J. Guerrero, G. A. Sarmiento, and M. A. Lorente 1995, Andean tectonics as a cause for changing drainage patterns in Miocene northern South America: Geology, v. 23, no. 3, p. 237-240, doi:10.1130/0091-7613(1995) 023<0237:ATAACF>2.3.CO;2.

Jordan, T. H., 1988, Structure and formation of the continental tectosphere: Journal of Petrology, Special Volume el, doi:10.1093/petrology/Special_Volume.1.11.

Kido, M., and T. Seno, 1994, Dynamic topography compared with residual depth anomalies in oceans and implications for age-depth curves: Geophysical Research Letters, v. 21, no. 8, p. 717-720, doi:10.1029/94GL00305.

Kirschner, J. P., M. A. Kominz, and K. E. Mwakanyamale 2010, Quantifying extension of passive margins: Implications for sea level change: Tectonics, v. 29, p. TC4005.

Kominz, M. A., 1984, Oceanic ridge volumes and sea level change: An error analysis, in J. Schlee, ed., Interregional unconformities and hydrocarbon accumulation: AAPG Memoir, v. 36, p. 109-127.

Kominz, M. A., 2001, Paleooceanography: Variations in sea level (MS 255), in J. Steele, S. Thorpe, and K. Turekian, eds., Encyclopedia of ocean sciences: San Diego, California, Academic Press, p. 2605-2613.

Kominz, M. A., J. V. Browning, K. G. Miller, P. J. Sugarman, S. Mizintseva, and C. R. Scotese, 2008, Late Cretaceous to Miocene sea level estimates from the New Jersey and Delaware coastal-plain coreholes: An error analysis: Basin Research, v. 20, no. 2, p. 211-226, doi:10.1111/j .1365-2117.2008.00354.x.

Langford, R. P., G. E. Wilford, E. M. Truswell, and A. R. Isern, 1995, Paleogeographic atlas of Australia: Canberra, Australia, Cainozoic Australian Geological Survey Organization, $38 \mathrm{p}$.

Lithgow-Bertelloni, C., and M. Gurnis, 1997, Cenozoic subsidence and uplift of continents from time-varying dynamic topography: Geology, v. 25, no. 8, p. 735-738, doi:10 $.1130 / 0091-7613(1997) 025<0735$ : CSAUOC $>2.3$ .CO;2.

Lithgow-Bertelloni, C., and P. G. Silver, 1998, Dynamic topography, plate driving forces and the African superswell: Nature, v. 395 , no. 6699, p. 269-272, doi:10.1038 /26212.

Liu, L., and M. Gurnis, 2008, Simultaneous inversion of mantle properties and initial conditions using an adjoint of mantle convection: Journal of Geophysical Research, v. 113, p. B08405, doi:10.1029/2008JB005594.

Liu, L., S. Spasojeviæ, and M. Gurnis, 2008, Reconstructing Farallon plate subduction beneath North America back to the Late Cretaceous: Science, v. 322, p. 934-938, doi:10.1126/science.1162921.

Liu, L., M. Gurnis, M. Seton, J. Saleeby, R. D. Muller, and J. M. Jackson, 2010, The role of oceanic plateau subduction in the Laramide orogeny: Nature Geoscience, v. 3, p. 353 357, doi:10.1038/ngeo829.

Liu, S. F., and D. Nummedal, 2004, Late Cretaceous subsidence in Wyoming: Quantifying the dynamic component: Geology, v. 32, no. 5, p. 397-400, doi:10.1130 /G20318.1.

Masters, G., G. Laske, H. Bolton, and A. Dziewonski, 2000, The relative behavior of shear velocity, bulk sound speed, and compressional velocity in the mantle: Implications for chemical and thermal structure, in S. Karato, et al., eds., Seismology and mineral physics: American Geophysical Union Geophysical Monograph Series, p. 63-88.

Miller, K. G., M. A. Kominz, J. V. Browning, J. D. Wright, G. S. Mountain, M. E. Katz, P. J. Sugarman, B. S. Cramer, N. Christie-Blick, and S. F. Pekar, 2005, The Phanerozoic record of global sea level change: Science, v. 310 , no. 5752 , p. 1293-1298, doi:10.1126/science .1116412

Mitrovica, J. X., and G. T. Jarvis, 1985, Surface deflections due to transient subduction in a convecting mantle: Tectonophysics, v. 120, no. 3-4, p. 211-237, doi:10.1016 /0040-1951(85)90052-6.

Mitrovica, J. X., C. Beaumont, and G. T. Jarvis, 1989, Tilting of continental interiors by the dynamical effects of subduction: Tectonics, v. 8, no. 5, p. 1079-1094, doi:10 .1029/TC008i005p01079.

Mitrovica, J. X., R. N. Pysklywec, C. Beaumont, and A. Rutty, 1996, The Devonian to Permian sedimentation of the Russian platform: An example of subduction-controlled long-wavelength tilting of continents: Journal of Geodynamics, v. 22, no. 1-2, p. 79-96, doi:10.1016/0264 -3707(96)00008-7.

Morley, C. K., and R. Westaway, 2006, Subsidence in the 
super-deep Pattani and Malay basins of Southeast Asia: A coupled model incorporating lower crustal flow in response to postrift sediment loading: Basin Research, v. 18, no. 1, p. 51-84, doi:10.1111/j.1365-2117.2006 .00285.x.

Müller, R. D., W. R. Roest, J. Y. Royer, L. M. Gahagan, and J. G. Sclater, 1997, Digital isochrons of the world's ocean floor: Journal of Geophysical Research, v. 102, no. B2, p. 3211-3214, doi:10.1029/96JB01781.

Müller, R. D., M. Sdrolias, C. Gaina, and W. R. Roest, 2008a, Age, spreading rates and spreading asymmetry of the world's ocean crust: Geochemistry, Geophysics, Geosystems, v. 9, p. Q04006, doi:10.1029/2007GC001743.

Müller, R. D., M. Sdrolias, C. Gaina, B. Steinberger, and C. Heine, 2008b, Long-term sea level fluctuations driven by ocean basin dynamics: Science, v. 319, no. 5868, p. 13571362, doi:10.1126/science.1151540.

Parsons, B., and J. G. Sclater, 1977, Analysis of variation of ocean-flow bathymetry and heat-flow with age: Journal of Geophysical Research, v. 82, no. 5, p. 803-827, doi: 10 .1029/JB082i005p00803.

Partridge, T. C., and R. R. Maud, 1987, Geomorphic evolution of southern Africa since the Mesozoic: South African Journal of Geology, v. 90, p. 179-208.

Richards, M. A., and B. H. Hager, 1984, Geoid anomalies in a dynamic Earth: Journal of Geophysical Research, v. 89, no. B7, p. 5987-6002, doi:10.1029/JB089iB07p05987.

Ritsema, J., H. J. van Heijst, and J. H. Woodhouse, 2004, Global transition zone tomography: Journal of Geophysical Research, v. 109, p. B02302, doi:10.1029 /2003JB002610.

Saleeby, J., 2003, Segmentation of the Laramide slab: Evidence from the southern Sierra Nevada region: Geological Society of America Bulletin, v. 115, no. 6, p. 655-668, doi:10.1130/0016-7606(2003) 115<0655:SOTLSF>2 .0.CO;2.

Sandiford, M., 2007, The tilting continent: A new constraint on the dynamic topographic field from Australia: Earth and Planetary Science Letters, v. 261, no. 1-2, p. 152163, doi:10.1016/j.eps1.2007.06.023.

Schellart, W. P., B. L. N. Kennett, W. Spakman, and M. Amaru, 2009, Plate reconstructions and tomography reveal a fossil lower mantle slab below the Tasman Sea: Earth and Planetary Science Letters, v. 278, no. 3-4, p. 143-151, doi:10.1016/j.epsl.2008.11.004.

Shepard, G. E., R. D. Muller, L. Liu, and M. Gurnis, 2010, Miocene Amazon River drainage reversal caused by platemantle dynamics: Nature Geoscience, v. 3, p. 870-875, doi:10.1038/ngeol017.

Simmons, N. A., A. M. Forte, and S. P. Grand, 2009, Joint seismic, geodynamic and mineral physical constraints on three-dimensional mantle heterogeneity: Implications for the relative importance of thermal versus compositional heterogeneity: Geophysical Journal International, v. 177, no. 3, p. 1284-1304, doi:10.1111/j.1365 -246X.2009.04133.x.

Sleep, N. H., 1976, Platform subsidence mechanisms and eustatic sea level changes: Tectonophysics, v. 36, no. 1-3, p. 45-56, doi:10.1016/0040-1951(76)90005-6.

Sloss, L. L., 1963, Sequences in the cratonic interior of North
America: Geological Society of America Bulletin, v. 74, no. 2, p. 93-114, doi:10.1130/0016-7606(1963)74[93 :SITCIO]2.0.CO;2.

Sloss, L. L., 1988, Tectonic evolution of the craton in Phanerozoic time, in L. L. Sloss, ed., Sedimentary cover: North American craton, U.S.A.: Boulder, Colorado, Geological Society of America, Geology of North America, v. D-2, p. 22-51.

Smith, A. G., D. G. Smith, and B. M. Funnel, 1994, Atlas of Mesozoic and Cenozoic coastlines: New York, Cambridge University Press, $112 \mathrm{p}$.

Spasojevic, S., L. Liu, M. Gurnis, and R. D. Müller, 2008, The case for dynamic subsidence of the United States East Coast since the Eocene: Geophysical Research Letters, v. 35, p. L08305, doi:10.1029/2008GL033511.

Spasojevic, S., L. Liu, and M. Gurnis, 2009, Adjoint models of mantle convection with seismic, plate motion and stratigraphic constraints: North America since the Late Cretaceous: Geochemistry, Geophysics, Geosystems, v. 10, p. Q05W02, doi:10.1029/2008GC002345.

Spasojevic, S., M. Gurnis, and R. Sutherland, 2010a, Inferring mantle properties with an evolving dynamic model of the Antarctica: New Zealand region from the Late Cretaceous: Journal of Geophysical Research-Solid Earth, v. 115, p. B05402, doi:10.1029/2009JB006612.

Spasojevic, S., M. Gurnis, and R. Sutherland, 2010b, Mantle upwellings above slab graveyards linked to the global geoid lows: Nature Geoscience, v. 3, p. 435-438, doi:10 $.1038 /$ ngeo855.

Spencer, A. M., ed., 1974, Mesozoic-Cenozoic orogenic belts: Data for orogenic studies: Edinburgh, Germany, Scottish Academic Press, 809 p.

Stadler, G., M. Gurnis, C. Burstedde, L. C. Wilcox, L. Alisic, and O. Ghattas, 2010, The dynamics of plate tectonics and mantle flow: From local to global scales: Science, v. 329 , no. 5995, p. 1033-1038, doi:10.1126/science .1191223 .

Stein, C., and S. Stein, 1992, A model for the global variation in oceanic depth and heat flow with lithospheric age: Nature, v. 359 , no. 6391 , p. 123-129, doi:10.1038 /359123a0.

Sutherland, R., S. Spasojevic, and M. Gurnis, 2009, Mantle upwelling after Gondwana subduction death may explain anomalous topography of West Antarctica and subsidence history of eastern New Zealand: Geology, v. 38, no. 2, p. 155-158, doi:10.1130/G30613.1.

Tan, E., E. Choi, P. Thoutireddy, M. Gurnis, and M. Aivazis, 2006, GeoFramework: Coupling multiple models of mantle convection within a computational framework: Geochemistry, Geophysics, Geosystems, v. 7, p. Q06001, doi:10.1029/2005GC001155.

van der Meer, D. G., W. Spakman, D. J. J. van Hinsbergen, M. L. Amaru, and T. H. Torsvik, 2010, Towards absolute plate motions constrained by lower mantle slab remnants: Nature Geoscience, v. 3, no. 1, p. 36-40, doi:10.1038 /ngeo708.

Watts, A. B., and M. S. Steckler, 1979, Subsidence and eustasy at the continental margin of eastern North America, in M. Talwani, W. Hay, and W. B. F. Ryan, eds., Deep drilling results in the Atlantic Ocean: Continental margins 
and paleoenvironment: American Geophysical Union Maurice Ewing Series, v. 3, p. 218-234.

Wheeler, P., and N. White, 2002, Measuring dynamic topography: An analysis of Southeast Asia: Tectonics, v. 21, no. 5, p. 1040, doi:10.1029/2001TC900023.

Whittaker, J. M., R. D. Müller, and M. Gurnis, 201 1, Development of the Australian-Antarctic depth anomaly: Geochemistry, Geophysics, Geosystems, v. 11, p. Q11006, doi:10.1029/2010GC003276.

Xu, X. Q., C. Lithgow-Bertelloni, and C. P. Conrad, 2006, Global reconstructions of Cenozoic sea floor ages: Implications for bathymetry and sea level: Earth and Planetary
Science Letters, v. 243, no. 3-4, p. 552-564, doi:10.1016 /j.eps1.2006.01.010.

Zhong, S. J., M. T. Zuber, L. Moresi, and M. Gurnis, 2000, Role of temperature-dependent viscosity and surface plates in spherical shell models of mantle convection: Journal of Geophysical Research, v. 105, no. B5, p. 1106311082, doi:10.1029/2000JB900003.

Zhong, S. J., A. McNamara, E. Tan, L. Moresi, and M. Gurnis, 2008, A benchmark study on mantle convection in a 3-D spherical shell using CitcomS: Geochemistry, Geophysics, Geosystems, v. 9, no. 10, p. Q10017, doi:10.1029 /2008GC002048. 